NBER WORKING PAPER SERIES

\title{
DID THE ELIMINATION OF MANDATORY RETIREMENT AFFECT FACULTY RETIREMENT FLOWS?
}

\author{
Orley Ashenfelter \\ David Card
}

Working Paper 8378

http://www.nber.org/papers/w8378

\author{
NATIONAL BUREAU OF ECONOMIC RESEARCH \\ 1050 Massachusetts Avenue \\ Cambridge, MA 02138 \\ July 2001
}

We thank David Ashmore for managing the data collection effort underlying this research, and Terry Layman, Linda Moskowitz, Ethan Lewis and Olivier Deschenes for their assistance in data collection and analysis. This project was funded by the Andrew W. Mellon Foundation and was conducted with the generous cooperation of TIAA/CREF and the participating institutions. We are grateful to William Bowen and John Biggs for their support and encouragement, and to seminar participants at the NBER and TIAA/CREF for helpful comments. The views expressed herein are those of the author and not necessarily those of the National Bureau of Economic Research.

(C) 2001 by Orley Ashenfelter and David Card. All rights reserved. Short sections of text, not to exceed two paragraphs, may be quoted without explicit permission provided that full credit, including $\odot$ notice, is given to the source. 
Did the Elimination of Mandatory Retirement Affect Faculty Retirement Flows?

Orley Ashenfelter and David Card

NBER Working Paper No. 8378

July 2001

JEL No. J26, I21

\section{$\underline{\text { ABSTRACT }}$}

A special exemption from the 1986 Age Discrimination Act allowed colleges and universities to enforce mandatory retirement of faculty at age 70 until 1994 . We compare faculty turnover rates at a large sample of institutions before and after the federal law change, and at a set of institutions that were covered by earlier state laws prohibiting compulsory retirement. Retirement rates at institutions that enforced mandatory retirement exhibited sharp "spikes" at ages 70 and 71. About 90 percent of professors who were still teaching at age 70 retired within two years. After the elimination of compulsory retirement the retirement rates of 70 and 71-year-olds fell to levels comparable to 69-year-olds, and over one-half of 70-year-olds were still teaching two years later. These findings indicate that U.S. colleges and universities will experience a rise in the number of older faculty over the coming years. The increase is likely to be larger at private research universities, where a higher fraction of faculty has traditionally remained at work until age 70 .

Orley Ashenfelter Department of Economics

Princeton University

Princeton, NJ 08544 and NBER
David Card

Department of Economics

UC Berkeley

Berkeley, CA 94720-3880

and NBER 
Over the past three decades the institution of mandatory retirement has all but disappeared from American life. College and university professors were among the handful of occupations exempted from the general prohibition of age-related employment barriers in the 1986 amendments of the Age Discrimination in Employment Act. The law granted a temporary exemption for postsecondary institutions to enforce mandatory retirement at age 70. The exemption was a hard-fought victory for college and university lobbyists, who argued that mandatory retirement was necessary to maintain a steady inflow of young faculty and promote the hiring of women and minorities. Following a review in the early 1990s, however, Congress allowed the exemption to expire, and mandatory retirement was eliminated on January 1, 1994. With this change, the U.S. became one of the few countries in the world to offer true lifetime employment security for tenured faculty members. ${ }^{1}$ The lifting of mandatory retirement occurred just as the wave of faculty hired in the early 1960s was about to reach traditional retirement age, prompting some critics to argue that the higher education system soon would be overwhelmed by a "gerontacracy" of aging teachers and scholars (Rosovsky, 1990, pp. 211-212).

This paper presents the first comprehensive study of the effect of the elimination of mandatory retirement on faculty retirement patterns. Our analysis is based on administrative records for 16,000 older faculty at 104 colleges and universities across the country. This new database - the Faculty Retirement Survey (FRS) - combines payroll records from individual schools with pension information from the TIAA-CREF pension plan. The FRS includes all regular faculty age 50 or older who were employed at a sample of four-year colleges and universities in the mid-1980s, and follows them for the next 10-11 years, yielding a rich source of information on faculty retirement flows in both the mandatory and post-mandatory eras.

${ }^{1}$ Many other developed countries, including the United Kingdom, Germany, and France, continue to allow mandatory retirement for most workers, including university faculty, although the U.K. government has proposed eliminating compulsory retirement (Sparrow, 2001). In Canada, mandatory retirement of university faculty was found constitutional in a 1990 Supreme Court decision. Australia and New Zealand eliminated mandatory retirement for most workers, including university faculty, in the late 1990s. 
We use the FRS to compare faculty retirement rates at different ages before and after the elimination of mandatory retirement. For faculty under the age of 70 we conclude that the elimination of mandatory retirement had no effect on retirement flows. Throughout our sample period three quarters of 60-year-old professors retired before reaching age 70, although the fraction remaining until 70 varies across institutions, with a higher rate at private research universities. In contrast, the elimination of mandatory retirement substantially reduced the retirement rates of 70 and 71-year-old professors. Prior to the law change the average retirement rate of 70 -year-olds was about 75 percent and the average for 71-year-olds was about 60 percent. Immediately afterward both rates fell to under 30 percent. These reductions have led to a marked increase in the fraction of faculty who continue working into their seventies. Whereas less than 10 percent of 70-year-old faculty was still employed at age 72 when mandatory retirement was in effect, currently about one-half of 70-year-old faculty are still working two years later.

In addition to providing evidence on the effect of mandatory retirement for postsecondary faculty, our findings illustrate several interesting features of retirement behavior. Individuals with higher salaries or lower pension wealth are less likely to retire at any given age. Retirement rates are also affected by relative salaries: faculty members with a higher rank in the salary distribution of their home institution have lower retirement rates, even controlling for the level of their salary. Finally, we test whether the elimination of mandatory retirement has led to a shift in the age structure of faculty salaries, as might be predicted by Lazear's (1979) model of the role of mandatory retirement in lifetime incentive contracts. We find surprisingly little change in the age structure: college and university professors have continued to experience modest salary growth in their 50's and 60's even after the lifting of mandatory retirement. 


\section{Background}

\section{a. Mandatory Retirement of Postsecondary Faculty}

In a provocative 1905 address to the Johns Hopkins medical school, William Osler, the outgoing chief physician, proposed that U.S. universities adopt mandatory retirement of professors at age $60 .^{2}$ While Osler's proposal led to no immediate action, over the next several decades many colleges and universities adopted mandatory retirement rules. As in other sectors of the U.S. economy, the introduction of mandatory retirement was tied to the availability of pensions. A central role was played by the Carnegie Foundation for the Advancement of Teaching, which was established by Andrew Carnegie in the same year as Osler's address to fund pensions for retiring professors from private nonsectarian colleges. Reflecting as much concern for the age structure of the professorate as for the plight of impoverished professors, Carnegie wrote that ..."able men hesitate to adopt teaching as a profession and many old professors whose places should be occupied by younger men cannot be retired." ${ }^{3}$ Initially, Carnegie Foundation pensions were available to retirees from only 52 colleges (Biggs, 2001). By 1916 the number of participating institutions had expanded and the funding requirements had grown too large for the foundation, and the system was converted into a contributory pension plan - the Teacher's Insurance Annuity Association (TIAA). In the 1920s and 1930s, pension plans and mandatory retirement spread to many state institutions. ${ }^{4}$

${ }^{2}$ Osler argued that faculty over 40 were unproductive and those over 60 were a nuisance. Graebner (1980, pp. 3-10) reproduces several paragraphs of the address and provides an interesting account of its reception.

${ }^{3}$ Quoted in Graebner (1980, p. 109)).

${ }^{4}$ For example, in 1932 Pennsylvania State University set up a group life and pension plan and instituted mandatory retirement at age 65 (Bezilla, 1985). See Costa (1998, pp. 166-172) for a discussion of the spread of "pension movement" in the 1920s and 1930s. 
By the 1970s, mandatory retirement was a nearly universal feature of academic life. ${ }^{5}$ A serious challenge to the institution was posed by the 1978 amendments to the Age Discrimination in Employment Act (ADEA), which outlawed mandatory retirement for most workers before age 70 . Extensive lobbying by college and university representatives managed to win a 4-year delay in the application of the law to postsecondary faculty. Effective July 1982, however, the compulsory retirement age in higher education was raised to 70. A similar effort resulted in an 8-year exemption from the 1986 amendments of the ADEA, which outlawed compulsory retirement altogether for most workers. ${ }^{6}$ The 1986 legislation called for a National Academy of Sciences review of the impact of the elimination of mandatory retirement in higher education, which was presented to Congress in 1991. The review (Hammond and Morgan, 1991) concluded that a continuing exemption for tenured faculty was unnecessary and Congress allowed it to expire on schedule on December 31, 1993.

\section{b. College Enrollment and the Age Distribution of Post-Secondary Faculty}

The implications of a shift in retirement patterns among postsecondary faculty depend critically on the relative size of the population of older faculty. Because entry into the professorate is concentrated at younger ages, the current age structure of college faculty is largely a reflection of historical hiring patterns, which in turn were driven by trends in postsecondary enrollment. ${ }^{7}$ Figure 1 shows two

${ }^{5}$ It is difficult to precisely estimate what fraction of postsecondary institutions had mandatory retirement provisions. Results from the FRS, and from an earlier study by Rees and Smith (1991) suggest that mandatory retirement was nearly universal. In the labor force as a whole about 40 percent of workers were covered by mandatory retirement in the early 1970s (Fields and Mitchell, 1984, p. 7), with higher coverage among better educated men in managerial occupations (Lazear, 1979).

${ }^{6}$ The specific wording of the exemption was as follows: "Nothing in this Act shall be construed to prohibit compulsory retirement of any employee who has attained 70 years of age, and who is serving under a contract of unlimited tenure (or similar arrangement providing for unlimited tenure) at an institution of higher education (as defined by Sec. 1201(a) of the Higher Education Act of 1965).

${ }^{7}$ Three quarters of all new hires in any given institution in the FRS are under age 40. The fraction of people entering the professorate as a whole who are under 40 is presumably much higher. 
alternative measures of the inflow of new students to the postsecondary education system over the 195596 period. The first is the number of first-time freshman enrollees at four-year institutions; the second is the number of new high school graduates enrolled in 2- or 4-year colleges. ${ }^{8}$ Both measures show rapid growth until the early 1970 s, and relative stagnation thereafter.

The growth in the number of college entrants up to 1970 was driven by a combination of rising cohort size (i.e., the baby boom) and rising enrollment rates among successive cohorts. Enrollment pressure in the 1960s led to a rapid expansion of the college and university system and a hiring boom for younger faculty. Although the number of college-age youth continued to rise over the next decade, the fraction who enrolled in college dropped sharply, leading to a stable inflow of college freshmen in the 1970s (see Card and Lemieux, 2001). Over the 1980s cohort size fell but enrollment rates rebounded, with the offsetting effects again leading to a roughly constant inflow of freshmen. The relative stability in enrollment inflows from 1970 to 1990 was associated with a prolonged era of depressed demand for new faculty (see Bowen and Sosa, 1989).

Rapid faculty growth in the 1960s and the subsequent slowdown in hiring created a "bulge" in the age distribution of college and university faculty that is still working its way through the system. This feature is illustrated in Figure 2, where we show the age distributions of U.S. faculty at four-year institutions in 1977, 1987, and 1996. The 1977 and 1987 data are taken from Bowen and Sosa (1989, Figure 2.1) and are derived from the Survey of Doctorate Recipients, while the 1996 data are derived from the FRS. (FRS data for 1987 are very similar to those reported by Bowen and Sosa). Reflecting the pace of hiring in the 1960s and early 1970s, the 1977 age distribution is highly skewed to toward younger faculty. Over the 1980s and 1990s the age distribution has gradually flattened and shifted to the

${ }^{8} \mathrm{New}$ high school graduates are individuals age 16-24 who obtained a high school graduation diploma within the past 12 months. Thus, the series of new high school graduate enrollees approximates the inflow of "first-time" entrants to both 2- and 4-year colleges. The divergence in the two series in the 1960s reflects the rapid expansion of the 2-year college system: since the early 1970s the fraction of all college students enrolled in 2-year colleges has been fairly stable (see Card and Lemieux, 2001). 
right, with a decline in the fraction under age 40 and a rise in the fraction over age 55. Between 1977

and 1996 the median age of faculty at 4-year institutions rose by eight years, from 40 to 48 . A key

implication of these shifts is that the fraction of faculty now at risk to be affected by changes in

retirement rates is higher today than in the past. For example, FRS data suggest that about 14 percent of

all faculty in 1996 were between the ages of 60 and 69. As the wave of faculty hired in the 1960s moves into their sixties, this fraction will continue to rise for another 5-10 years. The growing relative size of the older faculty population underscores the importance of understanding changes in retirement patterns associated with the recent lifting of mandatory retirement.

\section{c. Previous Research on Faculty Retirement}

Prior to the phase-out of the exemption that allowed colleges and universities to continue mandatory retirement, two key studies were conducted to evaluate the likely effect of the law - Rees and Smith (1991), and the National Academy of Science/National Research Council (NRC) study mandated by Congress (Hammond and Morgan, 1991). ${ }^{9}$ The Rees and Smith study is particularly interesting because it attempted to evaluate the effect of mandatory retirement by examining faculty retirement rates at colleges and universities in states that had already passed state laws banning mandatory retirement. ${ }^{10}$ Rees and Smith compared the distribution of retirement ages at 12 institutions that were covered by state laws prohibiting mandatory retirement to the distribution at 21 other institutions that were not covered by such laws. Contrary to expectations, their analysis suggested that the mean retirement age was lower at the "uncapped" institutions (those that were prohibited from enforcing mandatory retirement) than at the

${ }^{9}$ Previous research on the general issue of faculty retirement include Holden and Hansen (1989) and The Commission on College Retirement (1990). Bowen and Sosa (1989) also present some analysis of faculty retirement rates. Pencavel (1997) presents an analysis of the early retirement incentives offered to University of California faculty in the late 1980s and early 1990s. Clark, Ghent and Kreps (1998) and Ehrenberg, Matier and Fontanella (1998) present case studies of specific institutions.

\footnotetext{
${ }^{10}$ In many states these laws only applied to faculty at state institutions.
} 
"capped" institutions (those that could enforce mandatory retirement). Moreover, a comparison of retirement ages at capped and uncapped institutions showed a higher fraction of retirements at age 70 at the uncapped institutions than at the capped colleges and universities (Rees and Smith, Table 2-5). ${ }^{11}$ Based on this evidence, Rees and Smith concluded that the elimination of mandatory retirement was unlikely to have a significant effect on retirement flows at most institutions, although they cautioned that it might have a larger impact at institutions where more faculty remained employed until age 70 .

Unfortunately, Rees and Smith's comparison of retirement ages is potentially misleading because it fails to take into account the presence of older faculty who have not yet retired (i.e., the censoring of retirement ages.) This is an especially serious problem because at the time of their analysis the uncapped schools had operated without mandatory retirement for only a few years. Thus, many of the post-70 faculty at the uncapped schools had not yet retired. Another problem with their analysis is that the distribution of retirement ages among those who retire in a given interval depends on the relative number of faculty who are entering retirement age in that period. As shown in Figure 2, faculty age distributions were shifting to the right during the 1980s, presumably leading Rees and Smith to understate the relative fraction of retirees at higher ages.

The NRC study did not conduct an independent analysis of retirement flows, but it presented circumstantial evidence from a few uncapped institutions that seemed to support Rees and Smith's conclusion. In particular, the NRC study noted that only a handful of faculty remained employed after age 70 at the University of Wisconsin (where a state law eliminated mandatory retirement) and at Johns Hopkins University (which stopped enforcing mandatory retirement in the late 1980s). On the other hand, the NRC study also noted that the fraction of retirees leaving at age 70 or older varied widely

\footnotetext{
${ }^{11}$ Comparing the distributions of retirement ages at 5 public uncapped universities with those at 3 public capped universities, they found only 16 percent of retirements at exactly age 70 in the capped group, compared to 23 percent of retirements in the uncapped group. Similar results were found comparing retirement ages at capped and uncapped liberal arts colleges.
} 
across research universities, from less than 10 percent at several major state universities to more than 60 percent at some private research institutions (Hammond and Morgan, 1991, Table 3). These differences led the NRC study authors to echo Rees and Smith's conclusion that the elimination of mandatory retirement could have a bigger impact at private research institutions where faculty were more likely to remain employed into their late sixties.

\section{The Faculty Retirement Survey}

a. Design

The Faculty Retirement Survey (FRS) was developed to provide a large-scale longitudinal database of older faculty at four-year colleges and universities before and after the elimination of mandatory retirement. To simplify the data collection and analysis we decided to limit the FRS to faculty at the roughly 90 percent of four-year institutions that offer defined contribution pension plans through TIAA-CREF, and to use TIAA-CREF records as the source of pension information. ${ }^{12}$ Starting from a list of accredited four-year colleges in the National Science Foundation's CASPAR database, we used TIAACREF account records to draw up a sample universe of 1,198 institutions with significant TIAA-CREF representation. ${ }^{13}$ We then used a stratified random quota sampling scheme to select schools for inclusion in the FRS. The 16 sample strata represent the four geographic regions of the country (Northeast, South, Midwest, and West), cross-classified with the four "Carnegie classes" of institutional types (research universities, doctorate granting institutions, comprehensive institutions, and liberal arts

\footnotetext{
${ }^{12}$ Results from the 1992 National Survey of Postsecondary Faculty suggest that 90 percent of accredited 4-year institutions offer TIAA-CREF pension coverage - see US Department of Education (1997, Table 5.1).

${ }^{13}$ There were 1,454 accredited 4-year colleges in the U.S. in 1992 - see US Department of Education (1997). Relative to this universe, we exclude schools with limited or zero TIAA-CREF participation, and about 100 specialized professional schools.
} 
colleges). ${ }^{14}$ The original target sample was 35 research institutions, 20 doctorate-granting institutions, 25 comprehensive institutions, and 30 liberal arts colleges. The differential sampling rates reflected our desire to concentrate on institutions with larger numbers of faculty, and our experience in a pilot study, which suggested that research-oriented institutions are more likely to have high-quality and readilyaccessible payroll data.

Once a school was selected for the sample, a letter was sent to the head of the institution from the sponsors of the FRS study informing them of the objectives of the study and asking for their cooperation. We then contacted the institution to determine their willingness to participate and inquire about the availability of computerized payroll data. Institutions that were unwilling to participate or lacked computerized payroll data for at least five years were dropped from the study and replaced by another institution from the same sample stratum. Delays in finalizing participation of the selected institutions led us to stop data collection in late 1997 , when we had obtained data from a total of 100 institutions. ${ }^{15}$ In addition to the schools selected in this manner, we include in the FRS database four nonrandomly selected institutions that participated in a pilot study conducted in 1995 to judge the feasibility of the FRS design.

Participating institutions were asked to provide a complete set of payroll records for all regular tenured or tenure-track faculty (including permanent lectures) who were 45 or older as of September 1 , 1986, or at the earliest date that computerized records were readily available. The payroll data include individual salaries for each academic year from the baseline date forward, and information on the date

${ }^{14}$ See Carnegie Foundation for the Advancement of Teaching (1987) for a description of these classifications. The categories are defined on the basis of federal research funding received, number of $\mathrm{Ph} . \mathrm{D}$. degrees awarded, and relative size of professional or specialized undergraduate programs versus arts and sciences.

${ }^{15}$ One institution provided data but had no faculty over age 50 in 1986, and was subsequently dropped. 
and reason for any subsequent employment termination. We also collected basic descriptive information for each faculty member, including age, gender, race, education, and academic department.

In the final step of data assembly the payroll records were matched by name and social security number to pension accounts at TIAA-CREF. The TIAA-CREF data include the total value of all pension accounts as of January 1 of each calendar year from 1986 onward, along with the amounts of any pension contributions after 1986. It should be noted that faculty in the FRS may have other sources of pension wealth besides their TIAA-CREF account. This is especially likely for those who work at state institutions, since many public universities do not participate in TIAA-CREF, and others give faculty the option of joining TIAA-CREF or some other pension plan. ${ }^{16}$ Faculty may also have other personal retirement accounts, such as Keough accounts, that are excluded from our TIAA-CREF totals.

\section{b. Sample Representativeness}

We successfully recruited 33 research universities, 17 doctorate-granting institutions, 25 comprehensive institutions, and 29 liberal arts colleges to participate in the FRS. The final sample includes one-third of all research universities in the country, about 15 percent of all doctorate-granting institutions, and about 5 percent of the comprehensive colleges and liberal arts colleges. ${ }^{17}$ We can evaluate the representativeness of FRS by comparing the characteristics of older faculty in the FRS against those of older faculty in the 1993 National Survey of Postsecondary Faculty (NSPF). ${ }^{18}$ As

\footnotetext{
${ }^{16}$ Some public institutions have switched their pension plans over the years, so that faculty hired before a certain date are covered by one pension plan and those hired later are covered by another.

${ }^{17}$ Appendix Table 1 presents more detail on the sample universe and the final sample.

${ }^{18}$ Since the public use micro samples of the NSPF do not contain sufficiently rich detail on characteristics such as age and salary, we used the interactive data analysis system (DAS) operated by the National Center for Education Statistics to construct characteristics of the NSPF sample. The number of faculty in the NSPF is relatively small: approximately 1000 observations each at research and doctorate institutions, 1800 at comprehensive institutions, and 480 at liberal arts colleges.
} 
documented in Appendix Table 2, this comparison suggests that within each of the four Carnegie classifications the FRS sample is very similar to the NSPF sample. In particular, the FRS and NSPF samples have nearly identical age distributions, similar fractions of female and nonwhite professors, and similar mean salaries. The only significant discrepancy arises in average salaries for liberal arts colleges: relative to the NSPF, salaries for liberal arts faculty in the FRS are 18 percent higher. We suspect that this gap arises because the liberal arts colleges in the FRS tend to be larger than average, in part because of our requirement of at least 6 years of computerized payroll records. ${ }^{19}$ This differential should be kept in mind in interpreting our results.

\section{c. Sample Overview and Description of Mandatory Retirement Provisions Prior to 1994}

Although most institutions in the FRS enforced mandatory retirement until December 31, 1993, fourteen schools had eliminated mandatory retirement before that date. In all but one case this decision was driven by a state law that prohibited mandatory retirement. ${ }^{20}$ Table 1 shows the composition of institutions and older faculty in the overall FRS sample, and in three subgroups of institutions: those that were capped until the federal law took effect in 1994; those that uncapped relatively early (before 1989); and those that uncapped somewhat later (mainly in 1990 or 1991). The early uncapped group includes all institutions in Wisconsin, Maine, and Utah, along with one school that voluntarily eliminated mandatory retirement in the late 1980s. The later uncapped group includes public institutions in Alabama, Arizona,

\footnotetext{
${ }^{19}$ The average size for liberal arts colleges in the FRS is 98 tenured and tenure-track faculty in the FRS, versus 69 in the overall population. Several of the smallest liberal arts colleges that were contacted to participate in the FRS did not have such records. For the other three categories of schools the average number of tenured and tenure track faculty in the FRS is very similar to the average from the 1988 National Survey of Postsecondary Faculty.

${ }^{20}$ In a few cases the state law prohibited mandatory retirement at both public and private institutions (specifically, the statutes in Wisconsin, Maine, Montana, Nevada and Utah) whereas in most cases it applied only to public institutions. See Hammond and Morgan (1991, Table 1) and Rees and Smith 1991, page 6) for a list of state laws.
} 
Connecticut, Florida, Idaho, Louisiana, New Hampshire, New York, Texas, Virginia, and Wyoming and all institutions in Montana and Nevada.

A comparison of the characteristics of older faculty in the three subgroups of institutions reveals many similarities and a few key differences. Owing to the nature of the state laws, schools that uncapped before 1994 are more likely to be public institutions. On the other hand, the age distributions and fractions of female and nonwhite faculty are similar in the three subgroups, as are the fractions of faculty with a Ph.D., the fraction in arts and sciences (as compared to professional schools such as Engineering, Business, or Law), and average annual salaries at the sample baseline date. In all three subgroups of institutions the majority of older faculty is made up of white men, about 80 percent of faculty hold a Ph.D., 70 percent are full professors, and about one-half teach in the arts and sciences. The mean annual salary of older faculty at the sample baseline year (in most cases, 1986) was around $\$ 70,000$.

Overall, 83.6 percent of faculty in the FRS have a TIAA-CREF retirement account. This fraction varies substantially across schools, however, ranging from a low of 30 percent at a couple of state institutions to 100 percent at many private institutions. The fraction of faculty with TIAA-CREF accounts is relatively low in the early uncapped schools, and also somewhat below average in the later uncapped schools, reflecting the high fraction of state institutions in these subsamples. Among faculty with a TIAA-CREF account, mean pension wealth is about three times annual salary (the median ratio is 2.8, the mean is 3.3), although again there is some variation across schools, with a tendency for lower average wealth levels at a few public schools that offered state pension funds to faculty in the past. This observation underscores the incomplete nature of our pension wealth measure. An examination of the pension data reveals that faculty with higher salaries tend to have higher pension wealth, although the correlation is imperfect (the simple correlation coefficient is 0.28 ), reflecting differences in age and the number of years working at colleges that participate in TIAA-CREF, differences in pension contribution rates of current and previous employers, and the past history of pension allocation decisions. 


\section{Retirement Flows}

The FRS design allows us to develop a variety of measures of faculty retirement flows. In this paper we focus on 1-year exit rates (or hazard rates) defined for specific age groups and for specific reasons for leaving employment. We begin by defining the subset of individuals who are at risk to exit at a particular age. To account for the fact that the typical academic year starts in the early fall, we measure age as of September 1. Thus, the group at risk to retire at age 65 in a particular year consists of those who have reached their $65^{\text {th }}$ birthday by September 1 of that year and who were employed in the previous September. The mandatory retirement rate at age 65 is defined as the fraction of this at-risk group whose payroll records indicate that their date of separation is before September 1, and whose reason for separation is recorded as a compulsory retirement. ${ }^{21}$ We define voluntary retirements and "other exits" (quits, terminations, and people who leave because of disability) similarly.

Figure 3 shows the average exit rates at each age for older faculty at the capped schools in the FRS during the years from 1987 to 1993 (i.e., before the change in the federal law outlawed mandatory retirement). As has been found for other samples of U.S. workers, the retirement rate for college and university faculty rises discretely at age 62, when retirees are first eligible for social security benefits, and has another peak at age 65, when retirees are eligible for full social security benefits (see, e.g., Phelan and Rust, 1997; Lumsdaine, Stock and Wise, 1995; and Gruber and Wise, 2001). Between the ages of 66 and 69, the average faculty exit rate in the pre-mandatory era was 16.3 percent per year, with 15.0 percentage points of this total due to retirement and the balance attributable to other exits. At age 70 the overall exit rate was 76 percent. Interestingly, most of the rise in exit rates between 69 and 70 was attributable to a jump in the noncompulsory retirement rate, rather than to compulsory retirements. The

\footnotetext{
${ }^{21}$ Note that someone who works in the fall semester and retires in December at age 65 will be coded as retiring at age 66. An examination of the data for retirees suggested that almost all retirements take place at the end of the academic year. Thus, people whose birthdays fall after September typically work one year longer than those born earlier in the year.
} 
exit rate at age 71 was also quite high (65 percent), and includes a sizeable fraction of compulsory retirements. The high rate of retirement at age 71 is explained in part by the fact that many capped institutions allowed faculty to continue teaching if they were under 70 at the start of the fiscal year, which typically begins on July 1. Thus, individuals who turn 70 in July or August and retire as late as possible will be recorded as retiring at 71 by our conventions. ${ }^{22}$ In addition, some schools apparently allowed professors to continue teaching as long as they had not yet turned 71 as of the start of the term.

The patterns in Figure 3 suggest two important conclusions about faculty retirement in the premandatory era. First, age 70 was a nearly impermeable barrier for continued employment of faculty. Taking account of all forms of exit, only 8 percent $(=(1-0.76) \times(1-0.65))$ of those who were teaching in the year before their $70^{\text {th }}$ birthday were still employed two years later. Second, most of the exits at age 70 were recorded as normal or "voluntary" retirements. Of course many faculty who would have preferred to continue teaching after age 70 may have decided to voluntarily retire to avoid the embarrassment and/or unpleasantness of a forced retirement. Given the fact that employers could force faculty members to retire after age 70 , and the observed rise in voluntary retirements at age 70 , we do not believe it is useful to distinguish between voluntary and mandatory retirements. Consequently, in the remainder of the paper we focus on a simple classification of exits into retirements and other exits.

\section{a. Changes in Retirement Rates at the Capped Institutions After January 11994}

How did exit rates of faculty at various ages change after the elimination of mandatory retirement? A first answer is provided by comparing retirement rates at different ages in the capped institutions (those that maintained mandatory retirement until the change in the federal law) before and after 1994. Figure 4a shows average retirement rates at different ages in the pre-mandatory and post-

\footnotetext{
${ }^{22}$ Consistent with this observation, a high fraction (38 percent) of those who retire at 71 were born in July or August.
} 
mandatory periods for faculty at the 90 capped institutions in the FRS. Figure $4 \mathrm{~b}$ shows average rates of other nonretirement exits in the two periods. (Note that the scales of the vertical axes are very different in these two graphs). The data in the upper panel reveal that average retirement rates at ages 58 to 69 , and at ages $72-73$, were quite similar in the pre-mandatory and post-mandatory periods. Retirement rates at ages 70 and 71 were sharply lower in the post-mandatory era, and more nearly in line with rates at ages 69 and 72. In other words, after the lifting of mandatory retirement, the pronounced "spike" in retirement rates at ages 70 and 71 was nearly eliminated. Looking at quits and other nonretirement exits, it appears that rates were slightly lower after 1994 for all age groups (the average differential is 0.4 percentage points for ages 60 to70), with a notable drop at age 71 (3.2 percentage points with standard error 1.8) and at 72 (4.2 percentage points with standard error 3.5). Nevertheless, before 1994 only a small fraction of faculty at the capped institutions remained at work after age 70. Thus, the apparent "spikes" in the rate of other exits at ages 71 and 72 in the pre-mandatory era arises from the exit behavior of only a handful of individuals. ${ }^{23}$ Given this fact, the declines in the rate of other exits at ages 71 and 72 after the elimination of mandatory retirement are statistically insignificant.

While the results in Figure 4a suggest that average retirement rates were very similar before and after 1994 for all ages other than 70 or 71, it is important to check that this apparent stability is not masking underlying variability in age specific retirement rates over time. This concern is addressed in Figure 5, where we plot the average retirement rates at six different ages in each year from 1987 to 1996. Although there is some year-to-year variability, retirement rates at ages 60, 62, 65, and 68 are all relatively constant, with no obvious trend over the 1987-96 period. By comparison, the drops in the retirement rates of 70 and 71-year-olds between 1993 and 1994 are very pronounced. This evidence

\footnotetext{
${ }^{23}$ The rate of other exits at age 71 in the pre-1994 period is the result of behavior by 11 faculty ( 4 of whom died), while the rate of other exits at age 72 in the pre-1994 period is the result of behavior by 4 faculty (1 of whom died).
} 
suggests that these declines were attributable to the law change, rather than to other underlying factors that happened to coincide with the elimination of mandatory retirement.

Table 2 presents a series of comparisons of age-specific retirement rates before and after the elimination of mandatory retirement. We show the number of faculty at uncapped institutions in the FRS who were at risk of retiring at each age between 60 and 72, the average retirement rates in the 1987-93 and 1994-96 periods, and the difference in average retirement rates between the periods. As a check on whether this difference is confounded by changes in the composition of the sample at risk to retire in the two periods, the final column of the table shows an adjusted difference in retirement rates obtained from a series of logistic regression models. The models are fit separately by age and include 19 control variables and a simple dummy variable indicating whether the potential retirement event took place before or after 1994. The covariates are indicators for gender, nonwhite race, holding a Ph.D., geographic region of the U.S., Carnegie classification and public/private status of the institution, and indicators for six broad departmental categories. For comparability with the unadjusted differences in retirement rates, the estimated coefficients of the post-1994 dummy variable from the logistic regression are transformed into (approximate) estimates of the difference in the average probability of retirement before and after 1994.

An examination of the raw and adjusted differences in retirement rates in Table 2 confirms the key findings in Figure 4a. Apart from ages 70 and 71, retirement rates before and after 1994 were very similar. Indeed, none of the differences in retirement rates at ages other than 70 or 71 is even close to statistical significance. Moreover, the large drops in retirement rates observed for 70 and 71 year-old faculty are very similar whether or not adjustments are made for the changing characteristics of older faculty. 


\section{b. Comparisons of Retirement Rates at Capped and Uncapped Institutions Before 1994}

Another way to evaluate the impact of the elimination of mandatory retirement is to compare retirement flows at different institutions before 1994, when some schools had already eliminated mandatory retirement and others had not. This is the research design used by Rees and Smith (1991), although at the time of their study only a small number of institutions were uncapped, and most had been uncapped for only one or two years. Table 3 presents the results of such a comparison, utilizing retirement flows in the 3-year period from 1991 to 1993. The advantage of limiting the comparison to this period is that there are only two groups of schools: those that retained mandatory retirement (and did so until January 1994), and those that had uncapped sometime before 1991.

The patterns in Table 3 are similar to those in Table 2, and lead to the same conclusion about the effect of the elimination of mandatory retirement on retirement rates at ages 70 and 71 . In particular, the retirement rate at age 70 was 45 percentage points higher at the capped institutions than at the uncapped institutions in the early 1990s, while the retirement rate at age 71 was 32 percentage points higher. These differentials are remarkably similar to the declines in average retirement rates observed for the capped schools after 1994, and provide additional confirmation of the effect of mandatory retirement rules on retirement flows of 70 and 71-year-old faculty. Unlike the patterns in Table 2, however, there is some indication in Table 3 that retirement rates at earlier ages were slightly different at the uncapped institutions than at the schools that maintained compulsory retirement. Such differences suggest that the retirement profile of faculty at the uncapped institutions may not be an entirely appropriate counterfactual for the behavior of those at capped institutions in the absence of mandatory retirement. ${ }^{24}$

\footnotetext{
${ }^{24}$ In an earlier draft (Ashenfelter and Card, 2001, Appendix Table 2) we compared average retirement rates before and after the lifting of mandatory retirement at the three groups of institutions described in Table 1. These comparisons suggest that prior to the elimination of mandatory retirement, retirement rates were quite similar at the three groups of schools. After the lifting of mandatory retirement, however, retirement rates of 60-68 year-olds rose by 3-5 percentage points at schools that eliminated mandatory retirement before 1994, whereas they were relatively constant at other schools.
} 
Nevertheless, compared to the differences in retirement rates at ages 70 and 71 , the differences at earlier ages are quite small.

Further insight into the behavior of retirement rates at the early uncapped institutions is provided in Figure 6, which graphs the retirement rates of 70-year-old faculty by year for institutions that uncapped early (before 1990), later (1990 or 1991), or not until 1994. The patterns for all three sets of institutions suggest that the elimination of mandatory retirement led to a reduction in the retirement rate at age $70{ }^{25}$ The declines were similar for the institutions that uncapped in 1990-91 and those that retained mandatory retirement until 1994, but somewhat smaller at schools that uncapped before 1990 . The latter group of schools had relatively low retirement rates for 70-year-olds in the earliest years of the FRS sample, perhaps because some schools in the group eliminated mandatory retirement even before 1989. The number of 70-year-old faculty at the early uncapped schools is only 10-14 per year, however, so the differences in retirement rates in the pre-1989 period between these and other schools are not statistically significant.

\section{c. Pooled Models}

The results in Figures 4-6 and Tables 2-3 provide compelling evidence that the elimination of mandatory retirement led to a large reduction in faculty retirement rates at ages 70 and 71 , with little systematic change at other ages. Morever, the effects of uncapping are similar whether we compare changes in retirement rates before and after 1994 at institutions that remained uncapped until the federal law change, or differences in retirement rates between capped and uncapped institutions in the early 1990s. To probe these results even further, we fit a series of logistic regression models that combine the

\footnotetext{
${ }^{25}$ Graphs similar to those in Figure 6 for faculty age 71 are not very informative because of the very small numbers of 71-year-olds in the pre-mandatory era.
} 
data on retirement rates at different ages for all the institutions in the FRS sample. ${ }^{26}$ These models take the form

(1) $\log \{\mathrm{P}(i, a, t) /(1-\mathrm{P}(i, a, t))\}=\mathrm{X}(i, j, a, t) \beta+\mathrm{c}_{\mathrm{a}}(j, t)$,

where $\mathrm{P}(i, j, a, t)$ is the probability that individual $i$, who is employed at institution $j$ at age $a$ in year $t$ retires before the start of the next academic year, conditional on having remained in employment up to age $a, \mathrm{X}(i, j, a, t)$ represents a set of observed characteristics of individual $\mathrm{i}$ and institution $\mathrm{j}, \beta$ is a coefficient vector, and $\mathrm{c}_{\mathrm{a}}(\mathrm{j}, t)$ represents a set of baseline retirement probability parameters for people of age $a$ in year $t$ at institution $j$. A simple specification of the baseline retirement probabilities is (2) $\mathrm{c}_{\mathrm{a}}(j, t)=\mathrm{d}_{\mathrm{a}}+\Delta_{\mathrm{a}} \times 1[t \geq \operatorname{Uncap}(j)]$, where $1[\cdot]$ is the indicator function and $\operatorname{Uncap}(j)$ is the date that institution $\mathrm{j}$ uncapped. This specification includes an unrestricted parameter $\mathrm{d}_{\mathrm{a}}$ for the baseline retirement rate at each age under a mandatory retirement regime, and another parameter $\Delta_{\mathrm{a}}$ for the change in the probability of retirement at age $a$ after uncapping. A more parsimonious specification, suggested by the patterns in Figures 4-6, imposes the restriction that retirement rates at ages other than 70 and 71 are unaffected by the lifting of mandatory retirement (i.e., $\Delta_{\mathrm{a}}=0$ for $a \neq 70$ or 71 ).

Table 4 presents estimation results for a series of models based on equations (1) and (2). The specification in the first column of the table includes a full set of unrestricted baseline parameters for each age, and another set of interactions of the age effects with a post-uncapping indicator, but excludes any other control variables. The estimated coefficients of the post-uncapping interaction terms with ages 70 and 71 are shown in the first two rows of the table, while the approximate changes in the probability

${ }^{26}$ See Prentice and Kalbfleisch (1980), Allison (1982) and Efron (1988) for discussions of the use of logistic regression models to model hazard probabilities. Note that in the estimation we treat quits and other forms of exit as independent competing risks. 
of retirement for 70 and 71 -year-olds after uncapping are reported in the bottom rows of the table. ${ }^{27}$ Column 2 presents an expanded specification that adds 21 control variables (the 19 covariates used in the models in Table 2 plus two indicators for institutions that uncapped early and later). Although many of the control variables exert statistically significant effects on individual retirement probabilities, their inclusion has no effect on the estimated change in retirement rates for 70 or 71 -year-olds after uncapping.

The coefficients of the key covariates reported in Table 4 show some interesting patterns.

Retirement rates are higher at public research universities than at private comprehensive institutions (the omitted group in the models), while rates at private research universities are lower. Retirement rates are also higher at liberal arts colleges (all of which are private) than at the reference private comprehensive institutions. Finally, publicly controlled non research institutions have significantly higher retirement flows. Interestingly, the public-private difference in the log odds of retirement among the non research institutions is not much different from the corresponding public-private gap for research universities.

Turning to the coefficients of the individual faculty characteristics, the estimates suggest that nonwhites and individuals who hold a Ph.D. have lower average retirement rates. Women at research universities have slightly higher retirement rates than their male colleagues, whereas those at other institutions have comparable rates. ${ }^{28}$ Although the coefficients are not reported in the table, there are also some significant differences in retirement rates by region, discipline, and between the institutions that uncapped earlier versus later. Retirement rates at institutions in the West and Midwest are higher than those in the Northeast and South. Retirement rates for faculty in social sciences and physical

\footnotetext{
${ }^{27}$ Given the properties of the logit model, the model in column 1 of Table 4 leads to predicted probabilities of retirement for each age group before and after uncapping that exactly match the sample average probabilities. The reported changes in the probability of retirement are constructed using the approximation $\Delta_{\mathrm{a}} \times \mathrm{P}_{\mathrm{a}} \times\left(1-\mathrm{P}_{\mathrm{a}}\right)$ where $\mathrm{P}_{\mathrm{a}}$ is the average probability of retirement at age $a$ prior to uncapping.

${ }^{28} \mathrm{We}$ experimented with a number of other interactions between gender, race, and type of institution but found that only the female $\times$ research university interaction was statistically significant.
} 
sciences are significantly lower than those for faculty in humanities or life sciences, while retirement rates for faculty at professional schools tend to be higher than for other groups. Finally, retirement rates at schools that uncapped early (i.e., before 1990) or later (1990 or 1991) tend to be higher than at the institutions that maintained mandatory retirement until 1994.

The specification in column 3 of Table 4 is similar to the one in column 2, but it imposes the restriction that retirement rates are the same before and after uncapping at all ages except 70 and 71 . A comparison of the fit of this model to the fit of the specification in column 2 shows that this restriction is easily accepted (chi-square $=13.06$ with 13 degrees of freedom, $\mathrm{p}$-value $=0.44)$. Moreover, the coefficient estimates for the control variables are very similar in the two specifications.

The model in column 4 is fit to retirement outcomes in the period from 1987 to 1993. Identification of the effect of uncapping in this specification is obtained by comparing retirement probabilities before and after uncapping at institutions that eliminated mandatory retirement prior to the change in federal law, and to the rates at other institutions that maintained mandatory retirement until 1994. As suggested by the patterns in Table 3, the estimates of the effect of uncapping on retirement rates at ages 70 and 71 from this model are very similar to the estimate obtained using all the available data. In light of this similarity, we believe that the pooled specifications in the other columns of the table are justified.

The model in the fifth column of Table 4 is fit to the subset of individuals who are ages 65 or older. A comparison of the parameter estimates from this model to the estimates in column 3 provides an indication of whether the control variables have a differential effect at different ages, and whether such differences have any effect on inferences about the change in retirement probabilities for 70 and 71 -yearolds after uncapping. Although the estimated coefficients of some of the covariates are slightly different in the subsample of those age 65 and older, these differences have virtually no effect on the implied changes in retirement rates after uncapping. 
The models in columns 1-5 exclude controls for the salaries or pension wealth of individual faculty. Such controls are potentially important since standard economic models suggest that faculty members are less likely to retire if they can earn a higher salary, and more likely to retire if they expect a higher level of pension income during retirement (Lumsdaine and Mitchell, 1999, provide a comprehensive review of these models and empirical research on their implications). Moreover, although real salaries of older faculty were fairly constant over our sample period, pension wealth rose over the 1990s, leading to a potential difference between faculty who were at risk of retiring in the mandatory and post-mandatory periods. Column 6 reports a specification similar to the one in column 3 , but with the addition of a variable representing the log of the faculty member's real annual salary in the previous academic year. ${ }^{29}$ As expected, salary exerts a strong negative effect on retirement. On average, a faculty member with a 10 percent higher salary has about a 1 percent lower probability of retiring at ages 66-69 (conditional on having worked up to the previous year). ${ }^{30}$ The addition of salary information also leads to modest changes in the estimated effects of several other covariates that are correlated with salary, such as gender, race, and type of institution. ${ }^{31}$ Nevertheless, the introduction of controls for salary levels has little effect on the magnitude of the estimated changes in retirement rates at ages 70 and 71 after uncapping.

\footnotetext{
${ }^{29}$ Salary information is missing for a small fraction of observations. The characteristics of the subsample with observed salaries are very similar to those of the overall sample, and estimates for a model that excludes the salary variable are very similar in the subsample and the overall sample.

${ }^{30}$ The measured effects of a higher salary are not necessarily attributable to pay alone, since faculty with higher salaries may also have lower teaching loads, or may enjoy their work more.

${ }^{31}$ An analysis of salaries shows that average pay is similar at private comprehensive institutions, public doctorate-granting institutions, and liberal arts colleges. Relative to this reference group, salaries are about 25 percent higher at private research universities, 15 percent higher at public research universities, and 6 percent higher at private doctoral granting institutions. Among the older faculty in the FRS, women are paid 10 percent less than men and nonwhites are paid 2 percent less than whites, controlling for age, rank, full-time status, highest degree, and institutional characteristics.
} 
As noted in Table 1, only 84 percent of older faculty in the FRS has a TIAA-CREF pension account. The model in column 7 of Table 5 reproduces the specification from column 3 , but fit to the subset of observations that have valid data on both salary in the previous academic year and TIAA-CREF pension wealth. This subsample gives rise to parameter estimates that are fairly similar to the estimates for the overall sample. Finally, the model in column 8 includes controls for salary and pension wealth (as of December 31 of the previous calendar year). As in the specification in column 6, the estimates from this model suggest that salary exerts a strong negative effect on the probability of retirement. Pension wealth works in the opposite direction, but has a considerably smaller effect.

One concern with the estimated pension effect in column 8 is that we only observe an individual's TIAA-CREF retirement accounts and supplemental retirement accounts (SRA's). ${ }^{32}$ Measurement errors arising from the presence of other pension assets may bias the estimated effect of measured pension wealth. If the gap between total wealth and measured wealth is uncorrelated with measured wealth, then the coefficient on measured wealth will not be biased. More realistically, however, we suspect that people with higher wealth in TIAA-CREF accounts have less wealth in other assets, leading to a downward bias in the coefficient of measured wealth. Another problem is the potential endogeneity of SRA's, which are only held by one-third of older faculty in the FRS. To the extent that people who intend to retire earlier contribute more to an SRA, pension wealth will be negatively correlated with tastes for work, leading to a positive bias in the estimated pension wealth effect. We discuss some attempts to address the potential biases in the coefficient of measured pension wealth below. In any case, the estimates in column 8 suggest that the addition of controls for pension wealth has little effect on inferences about the changes in retirement rates at age 70 and 71 after uncapping.

${ }^{32}$ TIAA-CREF retirement accounts are the accounts whose value is based on previous contributions by the employer (or employers). SRA's are tax-sheltered individual contributory retirement plans similar to 403(b) plans, and subject to similar regulations. 


\section{d. Additional Specification Checks}

One limitation of the FRS is that we lack any data on nonpecuniary job conditions that may influence the retirement decisions of individual faculty. For example, teaching loads are often lighter for faculty who are deemed more productive by department chairs and deans. These faculty also typically receive the highest salaries in their respective institutions. This line of reasoning suggests that an individual's rank within the salary distribution of his or her institution may provide a reasonable proxy for working conditions (at least relative to those of other faculty in the same institution). In addition, salary rank may exert an independent effect on retirement. Table 5 presents a series of retirement models that include controls for various measures of salary rank, in place of or in addition to the level of salary. All of these models include the same controls as the models in Table 4, although for simplicity we show only the coefficients of the salary and rank terms, and the coefficients that represent the changes in retirement rates at ages 70 and 71 after the elimination of mandatory retirement. For reference purposes, column 1 reproduces the specification in column 6 of Table 4: this baseline model includes the log of (real) salary in the previous academic year, along with the 21 other control variables described earlier. The model in column 2 replaces the log of the individual's salary with the rank in the salary distribution of older faculty at his or her institution in the previous academic year (measured on a scale from 0 to 1 ), while the model in column 3 includes both the level of salary and salary rank, and the model in column 4 includes salary level, salary rank, and an indicator for being in the top 10 percent of the salary distribution of older faculty. These models suggest that both the absolute level of salary and salary rank influence the retirement decision. For example, according to the model in column 4, a faculty member in the $95^{\text {th }}$ percentile of the salary distribution of older faculty at his or her institution has a -0.36 lower log odds of retirement than one at the median of the salary distribution, controlling for the actual levels of their salaries. Nevertheless, the introduction of controls for salary rank has no effect on the measured impact of uncapping on retirement rates at ages 70 and 71, nor on the coefficients of the other control 
variables in the models. These conclusions also hold when pension wealth is added as an additional control variable (column 5).

A second and related problem with the FRS is that we lack information on various institutionwide characteristics that may influence faculty retirement rates. One way to address this shortcoming is to include controls for the identities of individual institutions (i.e., institution fixed effects). Assuming that institutional characteristics do not change when mandatory retirement is eliminated, institution fixed effects will control for any unobserved factors that may confound the comparison of retirement flows before and after uncapping. Table 6 presents a series of logistic retirement models that include a full set of unrestricted institutional fixed effects, as well as the individual-level controls included in our earlier models. A comparison of the estimates from these models to the results in Tables 4,5 and 6 allows us to assess the robustness of our inferences to the presence of permanent unobserved characteristics of different institutions.

Column 1 of Table 6 reports a specification similar to the one in column 3 of Table 4, except that it includes institution fixed effects. The estimated coefficients measuring the change in the probability of retirement at ages 70 and 71 after uncapping are very similar to estimates from the model without school effects, as are the coefficients of the faculty characteristics. Column 2 and 3 present models that include controls for salary and an individual's rank in the salary distribution of his or her institution. Results from these models are very similar to those from the models without school effects in Table 5, although the effect of salary rank is a smaller when institution fixed effects are included. Finally, column 4 adds controls for pension wealth. Compared to the parallel model in column 5 Table 5, the main difference is that the effect of pension wealth is larger in magnitude (the coefficient rises from 0.04 to 0.07 ). The implied changes in the retirement rates at ages 70 and 71 after uncapping are very stable across specifications, and robust to the presence or absence of school effects. 
Although not reported here, we have also fit linear probability models with and without school effects to assess the impact of a change in the functional form of the retirement model. Estimates of the effects of the elimination of mandatory retirement are very similar to those reported in the bottom rows of Tables 4-6. Moreover, the effects of the key control variables are similar in the linear probability and logistic models.

The final specification in Table 6 uses an alternative pension wealth variable that excludes SRA's. This model is motivated by the observation that the component of pension wealth attributable to employer pension contributions is arguably less correlated with unobserved taste factors than the component attributable to the employee's contributions (i.e., SRA's). To the extent that employercontributed pension wealth is independent of tastes for leisure, health, spousal earnings, and similar factors, it could be used as an instrumental variable for total pension wealth. Unfortunately, we can't implement such a procedure because total wealth is not observed. We can estimate a "reduced form" model that relates retirement propensities to employer-contributed pension wealth, and interpret the pension coefficient as the product of the true wealth effect and the elasticity of total pension wealth with respect to employer-contributed wealth. ${ }^{33}$ The resulting estimate of the effect of employer-provided pension wealth on retirement is only slightly smaller than the effect of total observed pension wealth (a coefficient of 0.06 versus 0.07 ). Comparing the other coefficients, there are only very small differences

\footnotetext{
${ }^{33}$ Formally, consider a two-equation model of retirement and wealth: $\mathrm{y}^{*}{ }_{1}=\mathrm{X} \alpha+\mathrm{y}_{2} \gamma+\epsilon_{1} ; \quad \mathrm{y}_{2}=\mathrm{P}+\mathrm{SRA}+\epsilon_{2}$ where $\mathrm{y}^{*}{ }_{1}$ is a latent variable measuring an individual's propensity to retire at a given age, $\mathrm{X}$ is a set of controls, $\mathrm{y}_{2}$ represents total pension wealth, $\epsilon_{1}$ represents an unobserved component of retirement propensity, $\mathrm{P}$ is the value of employer-provided pensions (i.e., TIAA-CREF retirement accounts), SRA is the value of any SRA accounts, and $\epsilon_{2}$ represents all other components of pension wealth. Let $\pi_{1}$ represent the coefficient of $\mathrm{P}$ when total pension wealth is regressed on $\mathrm{P}$ and $\mathrm{X}$, and let $\pi_{2}$ represent the coefficient of $\mathrm{P}$ in the "reduced form" model that relates $\mathrm{y}^{*}{ }_{1}$ to $\mathrm{P}$ and $\mathrm{X}$. Then $\pi_{2}=\gamma \pi_{1}$. We measure the wealth variables in logarithms so $\pi_{1}$ is the elasticity of total wealth with respect to $\mathrm{P}$ : $\pi_{1}=\mathrm{P} / \mathrm{y}_{2} \times(1+\mathrm{r})$, were $\mathrm{r}$ is the derivative of the total value of pension assets other than $\mathrm{P}$ with respect to a dollar increase in $\mathrm{P}$. In general, one would expect $-1<\mathrm{r}<0$, since people with higher $\mathrm{P}$ do not have to save as much in other assets to achieve the same retirement income. Thus, we expect $0<\pi_{2}<1$.
} 
between the estimates in columns 4 and 5 of Table 6 . These results do not suggest a serious bias in uncapping coefficients arising from the potential endogeneity of pension wealth. ${ }^{34}$

\section{e. Estimates of the Effect of Lifting Mandatory Retirement on Subgroups}

Up to this point we have been ignoring the possibility that the elimination of mandatory retirement had a differential effect on faculty at different types of institutions, or in different disciplines. Graphs of age-specific retirement rates before and after uncapping by Carnegie classification are very similar to Figure 3a, with large drops in retirement rates at 70 and 71 and few systematic changes at other ages (see Ashenfelter and Card, 2001). The upper panel of Table 7 shows the post-uncapping changes in retirement rates at ages 70 and 71 by institution type. As in Table 3, we show the unadjusted differences in age-specific retirement rates before and after uncapping as well as an adjusted difference obtained from a logistic regression model fit by age and institutional type. The results suggest that there were similar declines in average retirement rates at ages 70 and 71 across the different types of institutions, with the exception of the comprehensive institutions, where the changes were smaller. Given the relatively small numbers of observations at these institutions, however, the changes are not significantly different from those observed at other types of colleges and universities. Indeed, we cannot reject the hypothesis that the log odds of retirement at ages 70 and 71 fell by the same amount at the five types of institutions after uncapping.

\footnotetext{
${ }^{34} \mathrm{We}$ also tried using the individual share of TIAA-CREF assets allocated to equities versus bonds as an instrumental variable for pension wealth (in a linear probability framework). This fraction is an excellent predictor of pension wealth (controlling for salary, age, etc.), but is strongly negatively correlated with retirement probabilities, leading to an negative instrumental variables estimate of the pension wealth effect. We suspect that the share of assets in equities may itself be endogenous with respect to retirement plans, since people tend to reduce the equity share in the years just prior to retirement (relative to non-retirees of the same age). For what they are worth, the estimated effects of uncapping on the retirement rates of 70 and 71 year olds from the instrumental variables model are nearly identical to the estimates reported in Table 6.
} 
We have also compared age-specific retirement rates before and after uncapping for faculty in five sets of disciplines: humanities, social sciences, physical and life sciences (including mathematics), engineering, and business and professional schools. The patterns of relative retirement rates at different ages in the mandatory and post-mandatory eras are similar across disciplines, with uniform declines in retirement rates at ages 70 and 71 , and few systematic changes at other ages. The changes in average retirement rates at 70 and 71 are summarized in the lower panel of Table 7. As with the analysis across institutional categories, the declines in retirement rates across disciplines are similar enough that we cannot reject the hypothesis of equal effects. Perhaps surprisingly, the elimination of mandatory retirement had very similar effects on faculty retirement rates across all the disciplines.

\section{f. Summarizing the Effect of the Elimination of Mandatory Retirement on Faculty Flows}

The estimated exit rates for faculty at different ages derived from the FRS can be used to construct two key statistics that are useful in summarizing faculty retirement flows before and after the lifting of mandatory retirement. The first is the fraction of faculty who are employed at a given age (say 60) who can be expected to remain employed until age 70. The second is the fraction of those who are employed at age 70 who will remain teaching at ages $71,72,73$, etc. Estimates of these summary measures are presented in Table 8 . We show estimates for all faculty, for those at public and private research universities, and for those at other types of institutions (doctorate universities, comprehensive institutions, and liberal arts colleges). ${ }^{35}$

The upper panel of Table 8 shows estimated survival probabilities to age 70 for faculty who are ages 60 and 65. These survival probabilities incorporate the risks of both retirement and other exits (including quits and death). As might be expected given the evidence presented so far, the estimated

\footnotetext{
${ }^{35} \mathrm{We}$ have pooled doctorate, comprehensive, and liberal arts institutions to increase the reliability of the estimates.
} 
survival probabilities up to age 70 are very similar before and after the elimination of mandatory retirement. However, the fraction of older faculty that is expected to stay until age 70 varies widely across institutions, with a higher fraction at private research universities than at other institutions. As an illustration of this heterogeneity, Figure 7 graphs the frequency distributions of the institution-specific survival rates from age 60 to age 70 for private research universities, public research universities, and other institutions in the FRS. ${ }^{36}$ An important feature of this graph is the gap between private research universities and other institutions. The estimated survival probabilities for the private research universities in the FRS range from 25 to 80 percent, whereas at the public research and non research institutions the distribution of survival probabilities is concentrated below 40 percent.

The lower panel of Table 8 shows employment survival probabilities after age 70. Compared to the differences across institution types in the fraction of faculty who remain from age 60 to 70 , the post70 exit rates are remarkably homogeneous. In the mandatory era, only 8-10 percent of 70 year olds was still working two years later. Since the abolition of mandatory retirement this rate has risen to about 40 percent. Unfortunately, given the very small fraction of faculty who stayed past age 71 in the mandatory era and the relatively short time that elapsed between the lifting of mandatory retirement and the collection of the FRS data, we cannot reliably estimate survival probabilities beyond age 73 .

We can use the entries in the upper and lower panels of Table 8 to summarize the impact of the lifting of mandatory retirement on the expected fraction of older faculty who will continue working into their mid-70s. For example, when mandatory retirement was in place, only about 3 percent $(=0.413 \times 0.068)$ of 60 -year-old faculty at private research universities were still employed at age 73 . The fraction was even smaller at public research and non research institutions. In the post mandatory era the expected fraction of 60-year-olds who remain at work until 73 has risen to about 10 percent, on average,

\footnotetext{
${ }^{36}$ On the assumption that retirement rates prior to age 70 were unaffected by the elimination of mandatory retirement, these institution-specific survivor rates are estimated using data from the entire FRS sample period.
} 
but at some private research institutions where a very high fraction of faculty remains working in their sixties it is 30 percent or even higher. ${ }^{37}$ At the vast majority of public research universities and non research institutions the expected fraction is below 15 percent, although it is still 7-10 times higher than in the mandatory era.

\section{Have Wage Structures Adjusted After the Elimination of Mandatory Retirement?}

A final issue that we investigate is whether the elimination of mandatory retirement has led to any shift in the age structure of faculty salaries. Lazear (1979) proposed the now widely-accepted theory that mandatory retirement should be understood as part of an intertemporal incentive contract that pays workers low wages early in their careers and higher wages at later stages to reward continuing effort. A key assumption in this theory is that workers can be dismissed for under performance - an assumption that is not totally conformable with the institution of tenure in higher education. Nevertheless, some commentators have interpreted the high salaries of older faculty as a reward for lifetime effort (e.g., Siow, 1995). In Lazear's model, mandatory retirement is necessary because older workers are paid more than their value to the employer and will not choose to retire unilaterally. If this interpretation is correct, then one might expect the forced elimination of mandatory retirement to lead to pressure to alter the lifecycle wage profile and reduce the wage premium enjoyed by older faculty. Even apart from this model, the fact that higher salaries are associated with lower retirement rates might lead university administrators to reduce the rate of growth of salaries of older faculty to increase the incentives for voluntary retirement.

To measure any changes in the age structure of faculty salaries we assembled data for faculty in all age groups from a subset of 66 institutions that supplied their entire payroll records (not just data for

\footnotetext{
${ }^{37}$ For confidentiality reasons, we were not informed of the identities of the individual institutions in the FRS, so we cannot identify the schools with particularly high fractions of faculty who remain until 70.
} 
older faculty) to the FRS. This sample includes salaries and other information for about 33,000 faculty in each year from 1986 to 1996, representing all the tenured and tenure-track faculty at 23 research universities, 14 doctorate granting institutions, 10 comprehensive institutions, and 19 liberal arts colleges. ${ }^{38}$ We then fit a series of salary models by year that included unrestricted age dummies for each age from 24 to 74, controls for other individual characteristics (gender, race, highest degree, field) and unrestricted institution fixed effects. The age coefficients from the models for 1987 and 1996 are plotted in Figure $8 .^{39}$ There are some changes in the age structure of faculty salary from 1987 (just shortly after the passage of the amendments to the ADEA that ended mandatory retirement for most workers outside of higher education) to 1996 (5 years after the Congressional decision to end mandatory retirement of postsecondary faculty). There is no indication, however, of a systematic lowering of salaries for older (post-50) faculty relative to those of younger faculty. ${ }^{40}$ Based on this, we conclude that the elimination of mandatory retirement has not been associated with a shift in the age structure of pay for postsecondary faculty.

\section{$\underline{\text { V. Summary }}$}

In this paper we use data from a new longitudinal data base to estimate the effect of the elimination of mandatory retirement on faculty retirement behavior. This database - the Faculty

\footnotetext{
${ }^{38}$ The older faculty in this subsample are very similar to the overall sample we have analyzed so far.

${ }^{39}$ We use 1987 as our starting year because several schools were only able to provide computerized data starting in 1987. For comparability, the coefficients in Figure 8 are obtained from models fit to a subset of 51 schools that had data for every year from 1987 to 1996.

${ }^{40}$ The salary models in the two years are fairly similar, with R-squared coefficients of 0.39 in 1987 and 0.35 in 1996. One significant change is the female wage gap, which falls from - 0.173 (standard error $0.005)$ in 1987 to $-0.143(0.004)$ in 1996 . The wage gap for nonwhite faculty is small and insignificant in both years (0.005 in 1987, 0.007 in 1996). Interestingly, among faculty in the FRS there is no rise in overall wage inequality between 1987 and 1996 (the standard deviation of log annual wages is 0.32 in both years).
} 
Retirement Survey -- incorporates information on retirement flows for about 16,000 older faculty at a randomly selected sample of 104 colleges and universities across the United States. Comparisons of the characteristics of the faculty in the FRS to those in the 1993 National Survey of Postsecondary Faculty suggest that the FRS is a representative sample of older faculty at four-year colleges and universities.

We use the FRS to estimate faculty turnover rates (including retirements and other exits) by calendar year and age. Retirement rates at ages other than 70 and 71 were constant over the late 1980s and 1990s. Retirement rates at ages 70 and 71, however, fell by at least 50 percent after the elimination of mandatory retirement. In the mandatory era only 6 percent of those who were working at age 70 were employed three years later. Since the lifting of mandatory retirement this rate has risen to about 40 percent. We also use the FRS to estimate the fraction of faculty in their early sixties that will stay on to age 70. We estimate that about 40 percent of 60 -year-old faculty at private research universities will remain employed until age 70, compared with about 25 percent at public research universities, and just under 25 percent at doctoral granting, comprehensive, and liberal arts institutions.

Taken together, our findings suggest that a sizeable fraction of the cohort of college and university professors currently entering their sixties will remain employed into their mid-seventies. Although increases in the fraction of faculty over the age of 70 will be experienced at all types of institutions, the rises will be greatest at the private research universities, where a larger fraction of faculty has traditionally remained at work until age 70 . 


\section{References}

Allison, P. D. "Discrete-time Methods for the Analysis of Event Histories." In S. Leinhardt, editor Sociological Methodology. San Fransisco, CA: Josey-Bass, 1982.

Ashenfelter, Orley and David Card. "How Did the Elimination of Mandatory Retirement Affect Faculty Retirement?" Princeton University Industrial Relations Section Working Paper No. 448, October 2000.

Bezilla, Michael. Penn State: An Illustrated History. University Park, Pennsylvania: Pennsylvania State University Press, 1985.

Biggs, John H. "Pension Systems for the Academy and the Church: The Leadership of Andrew Carnegie and J.P. Morgan." Richard W. Couper Lecture to the Fellows of the Phi Beta Kappa Society, April 2001.

Bowen, William G. and Julie Ann Sosa. Prospects for Faculty Retirement in the Arts and Sciences. Princeton, NJ: Princeton University Press, 1989.

Card, David and Thomas Lemieux. "Dropout and Enrollment Trends in the Post-war Period: What Went Wrong in the 1970s?" In Jonathan Gruber, editor, Risky Behavior Among Youths: An Economic Analysis. Chicago: University of Chicago Press, 2001.

Carnegie Foundation for the Advancement of Teaching. A Classification of Institutions of Higher Education (1987 Edition). Princeton NJ: The Carnegie Foundation for the Advancement of Teaching, 1987.

Clark, Robert L., Linda S. Ghent, and Juanita Kreps. "Faculty Retirement and the Impact of the Elimination of Mandatory Retirement at Three North Carolina Universities". Unpublished manuscript, May 1998.

Commission on College Retirement. Pension and Retirement Policies in Colleges and Universities. San Francisco, CA: Josey-Bass, 1990.

Costa, Dora. The Evolution of Retirement: An American Economic History, 1880-1990. Chicago: University of Chicago Press, 1998.

Efron, Bradley. "Logistic Regression, Survival Analysis, and the Kaplan-Meier Curve." Journal of the American Statistical Association 83 (June) 1988.

Ehrenberg, Ronald G., Michael Matier, and David Fontanella. "Cornell University Confronts the End of Mandatory Retirement". Unpublished manuscript, May 1998.

Fields, Gary S. and Olivia S. Mitchell. Retirement, Pensions, and Social Security. Cambridge, Massachusetts: MIT Press, 1984.

Graebner, William. A History of Retirement. New Haven: Yale University Press, 1980. 
Gruber, Jonathan and David Wise. "Social Security, Retirement Incentives, and Retirement Behavior: An International Perspective." In Alan J. Auerbach and Ronald D. Lee, editors, Demographic Change and Fiscal Policy. New York: Cambridge University Press, 2001.

Hammond, P. Brett and Harriet P. Morgan, editors. Ending Mandatory Retirement for Tenured Faculty. Washington DC: National Academy Press, 1991.

Holden, Karen C. and W. Lee Hansen (editors). The End of Mandatory Retirement in Higher Education. San Francisco, CA: Jossey-Bass, 1989.

Lazear, Edward P. "Why Is There Mandatory Retirement?" Journal of Political Economy 87 (December 1979): 1261-1284.

Lumsdaine, Robin L., James H. Stock and David A. Wise. "Why Are Retirement Rates So High At Age 65?" National Bureau of Economic Research Working Paper Number 5190. Cambridge MA: NBER, 1995.

Lumsdaine, Robin L. and Olivia S. Mitchell. "New Developments in the Economic Analysis of Retirment". In Orley Ashenfelter and David Card, editors, Handbook of Labor Economics (volume 4). Amsterdam: North Holland, 1999.

Pencavel, John. "The Response of Employees to Severance Pay Incentives: Faculty of the University of California, 1991-94. Stanford University Department of Economics Unpublished Manuscript, July 1997.

Phelan, Christopher and John Rust. "How Social Security and Medicare Affect Retirement Behavior in a World of Incomplete Markets." Econometrica 65 (July 1997): 781-832.

Prentice, R. and J. Kalfleisch. The Statistical Analysis of Failure Time Data. New York: John Wiley, 1980.

Rees, Albert and Sharon P. Smith. Faculty Retirement in the Arts and Sciences. Princeton, NJ: Princeton University Press, 1991.

Rosovsky, Henry. The University : An Owner's Manual. New York: W. W. Norton, 1990.

Siow, Aloysius. "Specialization, Obsolescence, and Asymmetric Information in Academia." University of Toronto Department of Economics Working Paper UT-ECIPA-SIOW-95-02, November 1995.

Sparrow, Andrew. "Compulsory Retirement May be Banned". The Daily Telegraph (London), February 13, 2001. Available at www.globalaging.org/pension/world/compulsoryretirement.htm.

United States Department of Education, Office of Educational Research and Improvement. "1993 National Study of Postsecondary Faculty: Institutional Policies and Practices". Washington, DC: US Department of Education, 1997. 
Table 1: Characteristics of Institutions and Faculty by Uncapping Status

\begin{tabular}{|c|c|c|c|c|}
\hline & All & $\begin{array}{c}\text { Capped } \\
\text { Until } 1994 \\
\end{array}$ & $\begin{array}{l}\text { Early } \\
\text { Uncapped }\end{array}$ & $\begin{array}{l}\text { Later } \\
\text { Uncapped }\end{array}$ \\
\hline \multicolumn{5}{|l|}{ Number of Institutions: } \\
\hline Total & 104 & 90 & 5 & 9 \\
\hline Public Research & 18 & 11 & 1 & 6 \\
\hline Private Research & 15 & 14 & 1 & 0 \\
\hline Doctorate Granting & 17 & 16 & 0 & 1 \\
\hline Comprehensive & 25 & 22 & 1 & 2 \\
\hline Liberal Arts & 29 & 27 & 2 & 0 \\
\hline \multicolumn{5}{|l|}{ Faculty Characteristics: } \\
\hline $\begin{array}{l}\text { Number of Faculty } \\
\text { Age 50-plus }\end{array}$ & 16,724 & 13,682 & 1,073 & 1,969 \\
\hline Type of Institution (\%) & & & & \\
\hline Public Research & 49.2 & 41.8 & 73.7 & 87.2 \\
\hline Private Research & 20.7 & 23.9 & 18.5 & 0.0 \\
\hline Doctorate Granting & 12.9 & 14.9 & 0.0 & 5.8 \\
\hline Comprehensive & 12.0 & 13.4 & 3.4 & 7.0 \\
\hline Liberal Arts & 5.2 & 6.0 & 4.4 & 0.0 \\
\hline \multicolumn{5}{|l|}{ Age Distribution ( $\left.\frac{\circ}{0}\right)$ : } \\
\hline $50-54$ & 36.2 & 36.5 & 34.6 & 35.3 \\
\hline $55-59$ & 31.7 & 31.5 & 31.9 & 33.1 \\
\hline $60-64$ & 22.6 & 22.5 & 22.4 & 23.6 \\
\hline $65+$ & 9.4 & 9.5 & 11.2 & 8.0 \\
\hline Percent Female & 14.0 & 14.2 & 10.4 & 14.3 \\
\hline Percent Nonwhite & 8.1 & 8.1 & 6.2 & 9.1 \\
\hline Percent With Ph.D. & 81.5 & 80.8 & 84.2 & 84.9 \\
\hline Percent Full Professors & 71.3 & 70.8 & 89.0 & 64.6 \\
\hline Percent Arts\&Sciences & 54.0 & 54.0 & 51.0 & 55.8 \\
\hline Mean Salary (1996\$) & 68,900 & 68,000 & 74,000 & 72,600 \\
\hline Percent in TIAA-CREF & 83.6 & 87.0 & 58.0 & 72.1 \\
\hline Mean Pension (1996\$) & 234,800 & 240,600 & 106,300 & 225,700 \\
\hline
\end{tabular}


Table 2: Age-Specific Retirement Rates, Before and After 1994

\begin{tabular}{|c|c|c|c|c|c|c|}
\hline \multirow[b]{2}{*}{ Age } & \multirow{2}{*}{$\begin{array}{c}\text { Number } \\
\text { Of } \\
\text { Observations } \\
\end{array}$} & \multirow{2}{*}{$\begin{array}{l}\text { Percent } \\
\text { Post- } \\
1994 \\
\end{array}$} & \multicolumn{2}{|c|}{$\begin{array}{c}\text { Average } \\
\text { Retirement Rate }\end{array}$} & \multicolumn{2}{|c|}{ Change in Retirement Rate } \\
\hline & & & $1987-93$ & $1994-96$ & Unadjusted & $\begin{array}{l}\text { Adjusted } \\
\text { from Logit }\end{array}$ \\
\hline 60 & 7,343 & 31.8 & $\begin{array}{c}3.3 \\
(0.3)\end{array}$ & $\begin{array}{l}3.0 \\
(0.4)\end{array}$ & $\begin{array}{l}-0.3 \\
(0.4)\end{array}$ & $\begin{array}{l}-0.2 \\
(0.5)\end{array}$ \\
\hline 61 & 7,027 & 32.4 & $\begin{array}{c}4.1 \\
(0.3)\end{array}$ & $\begin{array}{c}4.4 \\
(0.4)\end{array}$ & $\begin{array}{c}0.3 \\
(0.5)\end{array}$ & $\begin{array}{c}0.3 \\
(0.5)\end{array}$ \\
\hline 62 & 6,665 & 32.9 & $\begin{array}{l}10.3 \\
(0.5)\end{array}$ & $\begin{array}{l}8.9 \\
(0.6)\end{array}$ & $\begin{array}{l}-1.4 \\
(0.8)\end{array}$ & $\begin{array}{l}-1.4 \\
(0.8)\end{array}$ \\
\hline 63 & 5,838 & 34.5 & $\begin{array}{c}8.5 \\
(0.5)\end{array}$ & $\begin{array}{l}7.3 \\
(0.6)\end{array}$ & $\begin{array}{l}-1.3 \\
(0.7)\end{array}$ & $\begin{array}{l}-1.1 \\
(0.8)\end{array}$ \\
\hline 64 & 5,222 & 35.4 & $\begin{array}{l}8.4 \\
(0.5)\end{array}$ & $\begin{array}{l}8.5 \\
(0.7)\end{array}$ & $\begin{array}{c}0.1 \\
(0.8)\end{array}$ & $\begin{array}{c}0.1 \\
(0.8)\end{array}$ \\
\hline 65 & 4,650 & 35.1 & $\begin{array}{l}19.3 \\
(0.7)\end{array}$ & $\begin{array}{l}18.1 \\
(1.0)\end{array}$ & $\begin{array}{l}-1.2 \\
(1.2)\end{array}$ & $\begin{array}{l}-1.4 \\
(1.3)\end{array}$ \\
\hline 66 & 3,653 & 35.1 & $\begin{array}{l}14.7 \\
(0.7)\end{array}$ & $\begin{array}{l}13.0 \\
(0.9)\end{array}$ & $\begin{array}{l}-1.7 \\
(1.2)\end{array}$ & $\begin{array}{l}-1.9 \\
(1.3)\end{array}$ \\
\hline 67 & 2,969 & 34.2 & $\begin{array}{l}13.8 \\
(0.8)\end{array}$ & $\begin{array}{l}14.0 \\
(1.1)\end{array}$ & $\begin{array}{c}0.1 \\
(1.3)\end{array}$ & $\begin{array}{l}-0.1 \\
(1.4)\end{array}$ \\
\hline 68 & 2,453 & 34.2 & $\begin{array}{l}14.3 \\
(0.9)\end{array}$ & $\begin{array}{l}14.6 \\
(1.2)\end{array}$ & $\begin{array}{l}0.4 \\
(1.5)\end{array}$ & $\begin{array}{c}0.7 \\
(1.5)\end{array}$ \\
\hline 69 & 2,004 & 33.7 & $\begin{array}{l}15.4 \\
(1.0)\end{array}$ & $\begin{array}{l}16.7 \\
(1.4)\end{array}$ & $\begin{array}{l}1.3 \\
(1.7)\end{array}$ & $\begin{array}{c}0.6 \\
(1.7)\end{array}$ \\
\hline 70 & 1,598 & 35.1 & $\begin{array}{l}75.6 \\
(1.3)\end{array}$ & $\begin{array}{l}29.1 \\
(2.0)\end{array}$ & $\begin{array}{r}-46.5 \\
(2.4)\end{array}$ & $\begin{array}{r}-43.7 \\
(2.5)\end{array}$ \\
\hline 71 & 502 & 58.6 & $\begin{array}{l}60.6 \\
(3.4)\end{array}$ & $\begin{array}{l}23.8 \\
(2.5)\end{array}$ & $\begin{array}{r}-36.8 \\
(4.2)\end{array}$ & $\begin{array}{r}-32.2 \\
(4.0)\end{array}$ \\
\hline 72 & 182 & 67.0 & $\begin{array}{l}16.7 \\
(4.9)\end{array}$ & $\begin{array}{l}25.4 \\
(4.0)\end{array}$ & $\begin{array}{l}8.7 \\
(6.3)\end{array}$ & $\begin{array}{l}-3.7 \\
(7.2)\end{array}$ \\
\hline
\end{tabular}

Notes: Retirement rates expressed as percent per year. Estimated standard errors in parentheses. An individual's retirement age is measured as of September 1 following the date of retirement. The adjusted change in retirement rates is the normalized regression coefficient from a logit model for the event of retirement, fit by age and including a total of 19 covariates: gender, $\mathrm{PhD}$, nonwhite race, region (3 dummies), Carnegie classification and public/private status of institution, and 6 department dummies. 
Table 3: Age-Specific Retirement Rates at Capped and Uncapped Institutions, 1991-1993

\begin{tabular}{|c|c|c|c|c|c|}
\hline \multirow[b]{2}{*}{ Age } & \multicolumn{2}{|c|}{ Capped Institutions } & \multicolumn{2}{|c|}{ Uncapped Institutions } & \multirow{2}{*}{$\begin{array}{c}\text { Difference: } \\
\text { Capped-Uncapped }\end{array}$} \\
\hline & Number & Rate & Number & Rate & \\
\hline 60 & 2486 & $\begin{array}{l}3.8 \\
(0.4)\end{array}$ & 573 & $\begin{array}{c}5.8 \\
(1.0)\end{array}$ & $\begin{array}{l}-2.0 \\
(1.0)\end{array}$ \\
\hline 61 & 2388 & $\begin{array}{l}5.2 \\
(0.5)\end{array}$ & 546 & $\begin{array}{l}5.1 \\
(0.9)\end{array}$ & $\begin{array}{c}0.1 \\
(1.0)\end{array}$ \\
\hline 62 & 2244 & $\begin{array}{l}10.2 \\
(0.6)\end{array}$ & 502 & $\begin{array}{l}10.8 \\
(1.4)\end{array}$ & $\begin{array}{l}-0.6 \\
(1.5)\end{array}$ \\
\hline 63 & 1936 & $\begin{array}{l}9.3 \\
(0.7)\end{array}$ & 436 & $\begin{array}{l}10.6 \\
(1.5)\end{array}$ & $\begin{array}{l}-1.3 \\
(1.6)\end{array}$ \\
\hline 64 & 1678 & $\begin{array}{l}8.3 \\
(0.7)\end{array}$ & 374 & $\begin{array}{l}8.6 \\
(1.4)\end{array}$ & $\begin{array}{l}-0.3 \\
(1.6)\end{array}$ \\
\hline 65 & 1496 & $\begin{array}{l}19.0 \\
(1.0)\end{array}$ & 368 & $\begin{array}{l}21.5 \\
(2.1)\end{array}$ & $\begin{array}{l}-2.5 \\
(2.4)\end{array}$ \\
\hline 66 & 1141 & $\begin{array}{l}14.3 \\
(1.0)\end{array}$ & 279 & $\begin{array}{l}17.2 \\
(2.3)\end{array}$ & $\begin{array}{l}-2.9 \\
(2.5)\end{array}$ \\
\hline 67 & 959 & $\begin{array}{l}14.0 \\
(1.1)\end{array}$ & 226 & $\begin{array}{l}22.1 \\
(2.8)\end{array}$ & $\begin{array}{l}-8.2 \\
(3.0)\end{array}$ \\
\hline 68 & 778 & $\begin{array}{l}14.9 \\
(1.3)\end{array}$ & 180 & $\begin{array}{l}17.8 \\
(2.9)\end{array}$ & $\begin{array}{l}-2.9 \\
(3.1)\end{array}$ \\
\hline 69 & 650 & $\begin{array}{l}17.1 \\
(1.5)\end{array}$ & 149 & $\begin{array}{l}15.4 \\
(3.0)\end{array}$ & $\begin{array}{l}1.6 \\
(3.3)\end{array}$ \\
\hline 70 & 542 & $\begin{array}{l}74.9 \\
(1.9)\end{array}$ & 124 & $\begin{array}{l}29.8 \\
(4.1)\end{array}$ & $\begin{array}{l}45.1 \\
(4.5)\end{array}$ \\
\hline 71 & 124 & $\begin{array}{l}61.3 \\
(4.4)\end{array}$ & 72 & $\begin{array}{l}29.2 \\
(5.4)\end{array}$ & $\begin{array}{l}32.1 \\
(7.0)\end{array}$ \\
\hline 72 & 39 & $\begin{array}{l}17.9 \\
(6.2)\end{array}$ & 30 & $\begin{array}{l}20.0 \\
(7.4)\end{array}$ & $\begin{array}{l}-2.1 \\
(9.7)\end{array}$ \\
\hline
\end{tabular}

Notes: Standard errors in parentheses. See notes to table 2. Sample is restricted to observations from 1991 to 1993. 
Table 4: Parameter Estimates for Pooled Logistic Hazard Model of Retirement

\begin{tabular}{|c|c|c|c|c|c|c|c|c|}
\hline & $\begin{array}{c}\text { No } \\
\text { Controls } \\
(1) \\
\end{array}$ & \multicolumn{2}{|c|}{$\begin{array}{c}\text { Full Sample } \\
\text { With Controls }\end{array}$} & $\begin{array}{c}\text { Pre- } \\
1994 \\
\text { Only } \\
(4)\end{array}$ & $\begin{array}{r}\text { Ages } \\
65+ \\
\text { Only } \\
(5) \\
\end{array}$ & $\begin{array}{l}\text { Subset } \\
\text { with } \\
\text { Wages } \\
\text { (6) }\end{array}$ & \multicolumn{2}{|c|}{$\begin{array}{l}\text { Subset with } \\
\text { Wage and } \\
\text { Pension Data } \\
\end{array}$} \\
\hline Age $70 \mathrm{x}$ Uncapped & $\begin{array}{l}-1.99 \\
(0.11)\end{array}$ & $\begin{array}{l}-2.11 \\
(0.11)\end{array}$ & $\begin{array}{l}-2.11 \\
(0.11)\end{array}$ & $\begin{array}{l}-2.18 \\
(0.20)\end{array}$ & $\begin{array}{l}-2.09 \\
(0.11)\end{array}$ & $\begin{array}{l}-2.19 \\
(0.11)\end{array}$ & $\begin{array}{l}-2.14 \\
(0.13)\end{array}$ & $\begin{array}{l}-2.18 \\
(0.13)\end{array}$ \\
\hline Age $71 \times$ Uncapped & $\begin{array}{l}-1.46 \\
(0.17)\end{array}$ & $\begin{array}{l}-1.55 \\
(0.17)\end{array}$ & $\begin{array}{l}-1.55 \\
(0.17)\end{array}$ & $\begin{array}{l}-1.39 \\
(0.29)\end{array}$ & $\begin{array}{l}-1.56 \\
(0.17)\end{array}$ & $\begin{array}{l}-1.67 \\
(0.19)\end{array}$ & $\begin{array}{l}-1.67 \\
(0.23)\end{array}$ & $\begin{array}{l}-1.66 \\
(0.23)\end{array}$ \\
\hline Other Ages x Uncapped & yes & yes & no & no & no & no & no & no \\
\hline \multicolumn{9}{|c|}{ Institutional Characteristics: } \\
\hline $\begin{array}{l}\text { Public Research } \\
\text { University }\end{array}$ & -- & $\begin{array}{c}0.24 \\
(0.07)\end{array}$ & $\begin{array}{c}0.24 \\
(0.07)\end{array}$ & $\begin{array}{l}0.26 \\
(0.08)\end{array}$ & $\begin{array}{c}0.23 \\
(0.09)\end{array}$ & $\begin{array}{c}0.48 \\
(0.07)\end{array}$ & $\begin{array}{l}0.38 \\
(0.09)\end{array}$ & $\begin{array}{l}0.54 \\
(0.09)\end{array}$ \\
\hline $\begin{array}{l}\text { Private Research } \\
\text { University }\end{array}$ & -- & $\begin{array}{l}-0.24 \\
(0.06)\end{array}$ & $\begin{array}{l}-0.25 \\
(0.06)\end{array}$ & $\begin{array}{l}-0.35 \\
(0.08)\end{array}$ & $\begin{array}{l}-0.27 \\
(0.09)\end{array}$ & $\begin{array}{l}0.00 \\
(0.07)\end{array}$ & $\begin{array}{l}-0.22 \\
(0.08)\end{array}$ & $\begin{array}{l}0.06 \\
(0.08)\end{array}$ \\
\hline $\begin{array}{l}\text { Doctorate-Granting } \\
\text { Institution }\end{array}$ & -- & $\begin{array}{c}0.09 \\
(0.06)\end{array}$ & $\begin{array}{c}0.10 \\
(0.06)\end{array}$ & $\begin{array}{l}-0.05 \\
(0.07)\end{array}$ & $\begin{array}{c}0.06 \\
(0.09)\end{array}$ & $\begin{array}{c}0.24 \\
(0.06)\end{array}$ & $\begin{array}{c}0.13 \\
(0.07)\end{array}$ & $\begin{array}{c}0.28 \\
(0.08)\end{array}$ \\
\hline Liberal Arts College & -- & $\begin{array}{c}0.34 \\
(0.08)\end{array}$ & $\begin{array}{c}0.34 \\
(0.08)\end{array}$ & $\begin{array}{l}0.28 \\
(0.10)\end{array}$ & $\begin{array}{c}0.37 \\
(0.11)\end{array}$ & $\begin{array}{c}0.47 \\
(0.08)\end{array}$ & $\begin{array}{c}0.47 \\
(0.09)\end{array}$ & $\begin{array}{c}0.57 \\
(0.09)\end{array}$ \\
\hline $\begin{array}{l}\text { Public Institution } \\
\text { (non-research) }\end{array}$ & -- & $\begin{array}{c}0.61 \\
(0.06)\end{array}$ & $\begin{array}{c}0.61 \\
(0.06)\end{array}$ & $\begin{array}{l}0.66 \\
(0.08)\end{array}$ & $\begin{array}{l}0.38 \\
(0.09)\end{array}$ & $\begin{array}{c}0.73 \\
(0.06)\end{array}$ & $\begin{array}{c}0.80 \\
(0.08)\end{array}$ & $\begin{array}{l}0.80 \\
(0.08)\end{array}$ \\
\hline \multicolumn{9}{|l|}{ Faculty Characteristics: } \\
\hline $\begin{array}{l}\text { Female at Research } \\
\text { University }\end{array}$ & -- & $\begin{array}{c}0.09 \\
(0.05)\end{array}$ & $\begin{array}{c}0.09 \\
(0.05)\end{array}$ & $\begin{array}{l}0.09 \\
(0.06)\end{array}$ & $\begin{array}{c}0.07 \\
(0.07)\end{array}$ & $\begin{array}{l}-0.03 \\
(0.05)\end{array}$ & $\begin{array}{l}0.09 \\
(0.06)\end{array}$ & $\begin{array}{l}-0.03 \\
(0.06)\end{array}$ \\
\hline $\begin{array}{l}\text { Female at other } \\
\text { Institution }\end{array}$ & -- & $\begin{array}{l}-0.02 \\
(0.07)\end{array}$ & $\begin{array}{l}-0.02 \\
(0.07)\end{array}$ & $\begin{array}{l}0.03 \\
(0.08)\end{array}$ & $\begin{array}{l}-0.17 \\
(0.07)\end{array}$ & $\begin{array}{l}-0.11 \\
(0.07)\end{array}$ & $\begin{array}{c}0.13 \\
(0.08)\end{array}$ & $\begin{array}{c}0.04 \\
(0.08)\end{array}$ \\
\hline Nonwhite & -- & $\begin{array}{l}-0.19 \\
(0.05)\end{array}$ & $\begin{array}{l}-0.19 \\
(0.05)\end{array}$ & $\begin{array}{l}-0.11 \\
(0.06)\end{array}$ & $\begin{array}{l}-0.18 \\
(0.07)\end{array}$ & $\begin{array}{l}-0.26 \\
(0.05)\end{array}$ & $\begin{array}{l}-0.26 \\
(0.07)\end{array}$ & $\begin{array}{l}-0.29 \\
(0.07)\end{array}$ \\
\hline Hold Ph.D. & -- & $\begin{array}{l}-0.22 \\
(0.04)\end{array}$ & $\begin{array}{l}-0.22 \\
(0.04)\end{array}$ & $\begin{array}{l}-0.26 \\
(0.04)\end{array}$ & $\begin{array}{l}-0.09 \\
(0.05)\end{array}$ & $\begin{array}{l}-0.16 \\
(0.04)\end{array}$ & $\begin{array}{l}-0.29 \\
(0.04)\end{array}$ & $\begin{array}{l}-0.20 \\
(0.05)\end{array}$ \\
\hline Log Wage Last Year & -- & -- & -- & -- & -- & $\begin{array}{l}-0.73 \\
(0.04)\end{array}$ & -- & $\begin{array}{l}-0.88 \\
(0.05)\end{array}$ \\
\hline Log Pension Last Year & -- & -- & -- & -- & -- & -- & -- & $\begin{array}{l}0.04 \\
(0.02)\end{array}$ \\
\hline $\begin{array}{l}\text { Controls for Region } \\
\text { and Department? }\end{array}$ & no & yes & yes & yes & yes & yes & yes & yes \\
\hline Implied Change in Mean & n Retire & ent $R$ & $A$ & 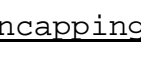 & $\left(\frac{\circ}{0}\right):$ & & & \\
\hline At Age 70 & $\begin{array}{r}-40.8 \\
(2.3)\end{array}$ & $\begin{array}{r}-43.3 \\
(2.2)\end{array}$ & $\begin{array}{r}-43.3 \\
(2.2)\end{array}$ & $\begin{array}{r}-44.9 \\
\quad(4.1)\end{array}$ & $\begin{array}{r}-42.8 \\
(2.3)\end{array}$ & $\begin{array}{r}-44.9 \\
(2.3)\end{array}$ & $\begin{array}{r}-43.9 \\
(2.5)\end{array}$ & $\begin{array}{r}-44.7 \\
\quad(2.5)\end{array}$ \\
\hline At Age 71 & $\begin{array}{r}-27.4 \\
(3.1)\end{array}$ & $\begin{array}{r}-29.3 \\
(3.1)\end{array}$ & $\begin{array}{r}-29.3 \\
(3.1)\end{array}$ & $\begin{array}{r}-26.1 \\
(5.4)\end{array}$ & $\begin{array}{r}-29.5 \\
(3.2)\end{array}$ & $\begin{array}{r}-31.6 \\
(3.6)\end{array}$ & $\begin{array}{r}-31.6 \\
(4.3)\end{array}$ & $\begin{array}{r}-31.4 \\
(4.3)\end{array}$ \\
\hline
\end{tabular}

Notes: Standard errors in parentheses. Models fit to retirement probabilities for ages 58-72 in 1987-96. All models include unrestricted age dummies for baseline retirement hazard. Other controls include 3 region dummies and 6 department dummies. Models in columns 1 and 2 include fully unrestricted age dummies for pre- and post-uncapping. other models assume uncapping only affects retirement rates at ages 70 and 71 . 
Table 5: Alternative Specifications of Logistic Retirement Model

\begin{tabular}{|c|c|c|c|c|c|}
\hline & \multicolumn{4}{|c|}{ Subset with Wage Data: } & \multirow{2}{*}{$\begin{array}{l}\text { Subset with } \\
\frac{\text { Wage\&Pension Data }}{(5)}\end{array}$} \\
\hline & $(1)$ & $(2)$ & (3) & (4) & \\
\hline Age 70 x Uncapped & $\begin{array}{l}-2.19 \\
(0.11)\end{array}$ & $\begin{array}{l}-2.20 \\
(0.11)\end{array}$ & $\begin{array}{l}-2.20 \\
(0.11)\end{array}$ & $\begin{array}{l}-2.20 \\
(0.11)\end{array}$ & $\begin{array}{l}-2.19 \\
(0.12)\end{array}$ \\
\hline Age 71 x Uncapped & $\begin{array}{l}-1.67 \\
(0.19)\end{array}$ & $\begin{array}{l}-1.71 \\
(0.19)\end{array}$ & $\begin{array}{l}-1.68 \\
(0.19)\end{array}$ & $\begin{array}{l}-1.69 \\
(0.19)\end{array}$ & $\begin{array}{l}-1.68 \\
(0.23)\end{array}$ \\
\hline Log Wage Last Year & $\begin{array}{l}-0.73 \\
(0.04)\end{array}$ & -- & $\begin{array}{l}-0.51 \\
(0.06)\end{array}$ & $\begin{array}{l}-0.51 \\
(0.06)\end{array}$ & $\begin{array}{l}-0.64 \\
(0.07)\end{array}$ \\
\hline $\begin{array}{l}\text { Rank in Salary } \\
\text { Distribution (0 to } 1)\end{array}$ & -- & $\begin{array}{l}-0.86 \\
(0.05)\end{array}$ & $\begin{array}{l}-0.37 \\
(0.07)\end{array}$ & $\begin{array}{l}-0.26 \\
(0.08)\end{array}$ & $\begin{array}{l}-0.32 \\
(0.10)\end{array}$ \\
\hline $\begin{array}{l}\text { Indicator if in Top } \\
\text { 10\% of Salaries }\end{array}$ & -- & -- & -- & $\begin{array}{l}-0.24 \\
(0.06)\end{array}$ & $\begin{array}{l}-0.18 \\
(0.07)\end{array}$ \\
\hline Log Pension Last Year & -- & -- & -- & -- & $\begin{array}{c}0.04 \\
(0.02)\end{array}$ \\
\hline $\begin{array}{l}\text { Controls for Faculty } \\
\text { and Institution } \\
\text { Characteristics }\end{array}$ & yes & yes & yes & yes & yes \\
\hline Implied Change in Mean & Retirem & $t$ Rate A & U Uncapr & $\mathrm{ng} \quad(\%)$ & \\
\hline At Age 70 & $\begin{array}{r}-44.9 \\
(2.3)\end{array}$ & $\begin{array}{r}-45.1 \\
(2.2)\end{array}$ & $\begin{array}{r}-45.1 \\
(2.2)\end{array}$ & $\begin{array}{r}-45.1 \\
(2.3)\end{array}$ & $\begin{array}{r}-44.9 \\
(2.7)\end{array}$ \\
\hline At Age 71 & $\begin{array}{r}-31.6 \\
(3.6)\end{array}$ & $\begin{array}{r}-32.3 \\
(3.6)\end{array}$ & $\begin{array}{r}-31.8 \\
(3.6)\end{array}$ & $\begin{array}{r}-31.9 \\
(3.6)\end{array}$ & $\begin{array}{r}-31.8 \\
(4.5)\end{array}$ \\
\hline
\end{tabular}

Notes: Standard errors in parentheses. Models fit to retirement probabilities for ages 58-72 in 1987-96. All models include unrestricted age dummies for baseline retirement hazard, controls for type of institution, gender and race, region and department. Models assume uncapping only affects retirement rates at ages 70 and 71 . 
Table 6: Logistic Retirement Models with Institution Fixed Effects

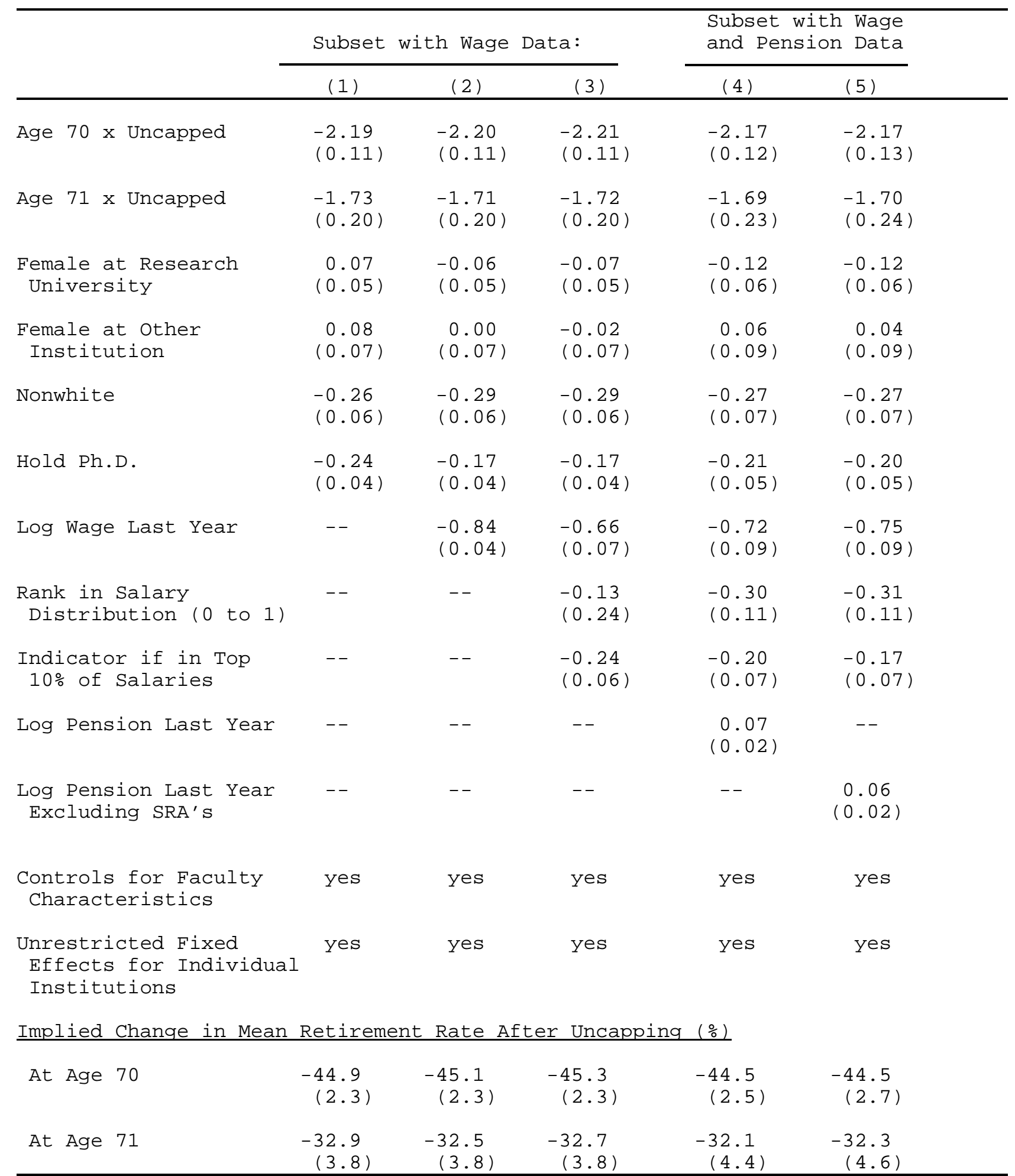

Notes: Standard errors in parentheses. Models fit to retirement probabilities for ages 58-72 in 1987-96. All models include unrestricted age dummies for baseline retirement hazard, controls for region and department, and unrestricted fixed effects for individual institutions in the sample. Models assume uncapping only affects retirement rates at ages 70 and 71 . 
Table 7: Retirement Rates at Ages 70 and 71, Before and After Elimination of Mandatory Retirement

\begin{tabular}{|c|c|c|c|c|c|c|c|c|c|c|}
\hline & $\begin{array}{c}\text { Number } \\
\text { Obs. }\end{array}$ & Caverag & $\frac{\text { ye Rate: }}{\text { Uncapped }}$ & $\begin{array}{l}s \text { at Age } \\
\text { Change } \\
\text { Unadj. }\end{array}$ & $\begin{array}{l}70 \\
\text { in Rate: } \\
\begin{array}{l}\text { Adjusted } \\
\text { (Logit) }\end{array}\end{array}$ & $\begin{array}{c}\text { Number } \\
\text { Obs. }\end{array}$ & Caverag & Ue Rate: & $\begin{array}{l}\text { at Age } 7 \\
\text { Change } \\
\text { Unadj. }\end{array}$ & $\begin{array}{l}\text { n Rate: } \\
\text { djusted } \\
\text { (Logit) }\end{array}$ \\
\hline \multicolumn{11}{|c|}{ By Carnegie Classification: } \\
\hline 1. Public Research & 834 & $\begin{array}{l}79.1 \\
(1.9)\end{array}$ & $\begin{array}{l}29.2 \\
(2.3)\end{array}$ & $\begin{array}{r}-49.9 \\
(3.0)\end{array}$ & $\begin{array}{r}-47.5 \\
(3.7)\end{array}$ & 304 & $\begin{array}{l}70.1 \\
(5.3)\end{array}$ & $\begin{array}{l}25.1 \\
(2.9)\end{array}$ & $\begin{array}{r}-45.0 \\
(6.0)\end{array}$ & $\begin{array}{r}-44.6 \\
(6.6)\end{array}$ \\
\hline 2. Private Research & 656 & $\begin{array}{l}72.6 \\
(2.2)\end{array}$ & $\begin{array}{l}27.4 \\
(3.0)\end{array}$ & $\begin{array}{c}-45.1 \\
(3.7)\end{array}$ & $\begin{array}{c}-37.4 \\
(3.9)\end{array}$ & 220 & $\begin{array}{l}58.9 \\
(5.1)\end{array}$ & $\begin{array}{l}23.2 \\
(3.8)\end{array}$ & $\begin{array}{r}-35.7 \\
(6.4)\end{array}$ & $\begin{array}{r}-31.8 \\
(6.3)\end{array}$ \\
\hline 3. Doctorate & 244 & $\begin{array}{l}77.4 \\
(3.6)\end{array}$ & $\begin{array}{l}30.6 \\
(4.4)\end{array}$ & $\begin{array}{r}-46.8 \\
(5.7)\end{array}$ & $\begin{array}{r}-56.7 \\
(7.6)\end{array}$ & 79 & $\begin{array}{c}54.2 \\
(10.4)\end{array}$ & $\begin{array}{l}27.3 \\
(6.1)\end{array}$ & $\begin{array}{l}-26.9 \\
(12.1)\end{array}$ & $\begin{array}{l}-29.2 \\
(15.2)\end{array}$ \\
\hline 4. Comprehensive & 141 & $\begin{array}{l}58.5 \\
(5.5)\end{array}$ & $\begin{array}{l}28.8 \\
(5.9)\end{array}$ & $\begin{array}{c}-29.7 \\
(8.1)\end{array}$ & $\begin{array}{c}-30.1 \\
(9.1)\end{array}$ & 56 & $\begin{array}{l}34.6 \\
(9.5)\end{array}$ & $\begin{array}{l}33.3 \\
(8.8)\end{array}$ & $\begin{array}{c}-1.3 \\
(12.9)\end{array}$ & $\begin{array}{l}-10.6 \\
(18.1)\end{array}$ \\
\hline 5. Liberal Arts & 78 & $\begin{array}{l}70.2 \\
(6.7)\end{array}$ & $\begin{array}{l}25.8 \\
(8.0)\end{array}$ & $\begin{array}{l}-44.4 \\
(10.5)\end{array}$ & $\begin{array}{l}-36.9 \\
(13.4)\end{array}$ & 33 & $\begin{array}{c}53.3 \\
(13.3)\end{array}$ & $\begin{array}{l}16.7 \\
(9.0)\end{array}$ & $\begin{array}{l}-36.6 \\
(16.1)\end{array}$ & $\begin{array}{l}-17.8 \\
(28.2)\end{array}$ \\
\hline \multicolumn{11}{|l|}{ By Department: } \\
\hline 1. Humanities & 367 & $\begin{array}{l}77.7 \\
(2.8)\end{array}$ & $\begin{array}{l}21.1 \\
(3.4)\end{array}$ & $\begin{array}{r}-56.6 \\
(4.4)\end{array}$ & $\begin{array}{r}-47.9 \\
(5.0)\end{array}$ & 132 & $\begin{array}{l}54.3 \\
(8.5)\end{array}$ & $\begin{array}{l}28.9 \\
(4.6)\end{array}$ & $\begin{array}{c}-25.4 \\
(9.7)\end{array}$ & $\begin{array}{l}-29.2 \\
(10.7)\end{array}$ \\
\hline 2. Social Science & 377 & $\begin{array}{l}80.5 \\
(2.7)\end{array}$ & $\begin{array}{l}30.6 \\
(3.7)\end{array}$ & $\begin{array}{r}-49.9 \\
(4.6)\end{array}$ & $\begin{array}{r}-47.6 \\
(5.5)\end{array}$ & 125 & $\begin{array}{l}60.5 \\
(8.0)\end{array}$ & $\begin{array}{l}26.4 \\
(4.8)\end{array}$ & $\begin{array}{r}-34.1 \\
(9.3)\end{array}$ & $\begin{array}{c}-40.6 \\
(11.1)\end{array}$ \\
\hline 3. Sciences & 437 & $\begin{array}{l}76.6 \\
(2.7)\end{array}$ & $\begin{array}{l}31.6 \\
(3.4)\end{array}$ & $\begin{array}{r}-45.0 \\
(4.3)\end{array}$ & $\begin{array}{r}-44.3 \\
(5.2)\end{array}$ & 151 & $\begin{array}{l}77.5 \\
(6.7)\end{array}$ & $\begin{array}{l}23.4 \\
(4.0)\end{array}$ & $\begin{array}{r}-54.1 \\
(7.8)\end{array}$ & $\begin{array}{r}-49.8 \\
(9.5)\end{array}$ \\
\hline 4. Engineering & 201 & $\begin{array}{l}68.6 \\
(4.3)\end{array}$ & $\begin{array}{l}26.3 \\
(5.0)\end{array}$ & $\begin{array}{r}-42.3 \\
(6.5)\end{array}$ & $\begin{array}{l}-33.9 \\
(7.0)\end{array}$ & 82 & $\begin{array}{l}53.6 \\
(9.6)\end{array}$ & $\begin{array}{l}33.3 \\
(6.5)\end{array}$ & $\begin{array}{l}-20.2 \\
(11.6)\end{array}$ & $\begin{array}{c}-9.6 \\
(15.1)\end{array}$ \\
\hline $\begin{array}{l}\text { 5. Professional, } \\
\text { Business and } \\
\text { Unknown }\end{array}$ & 571 & $\begin{array}{l}69.4 \\
(2.5)\end{array}$ & $\begin{array}{l}30.8 \\
(3.0)\end{array}$ & $\begin{array}{r}-38.7 \\
(3.9)\end{array}$ & $\begin{array}{r}-36.9 \\
(4.3)\end{array}$ & 206 & $\begin{array}{l}54.6 \\
(5.1)\end{array}$ & $\begin{array}{l}19.3 \\
(3.8)\end{array}$ & $\begin{array}{r}-35.4 \\
(6.3)\end{array}$ & $\begin{array}{r}-31.9 \\
(6.2)\end{array}$ \\
\hline
\end{tabular}

Notes: Standard errors in parentheses. Unadj. change in rate refers to simple difference in average retirement rates before and after uncapping. Adjusted change refers to a normalized coefficient estimate from a logistic regression model that controls for covariates listed in Table 3. 
Table 8: Estimated Probabilities of Remaining Employed Until Age 70, and Remaining Employed After Age 70

Faculty Affected by Mandatory Retirement

Research

All

Public Private Others

Probability of Staying to Age 70 (percent):

$\begin{array}{lllllllll}\text { from Age } 60 & 26.1 & 20.5 & 41.3 & 23.0 & 25.4 & 22.0 & 39.0 & 22.9 \\ \text { from Age } 65 & 39.2 & 31.7 & 54.2 & 37.2 & 38.6 & 34.9 & 50.7 & 35.6\end{array}$

Employment Outcomes For those Working at Age 70 (percent):

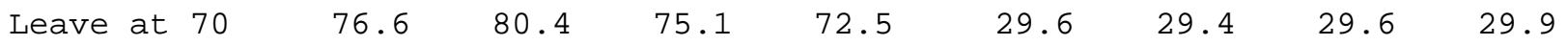

Still Employed:

$\begin{array}{lrrrrrrrr}\text { at Age } 71 & 23.4 & 19.6 & 24.9 & 27.5 & 70.4 & 70.5 & 70.4 & 70.1 \\ \text { at Age } 72 & 8.4 & 5.6 & 8.6 & 13.0 & 51.6 & 52.5 & 52.9 & 48.3 \\ \text { at Age } 73 & 6.3 & 3.5 & 6.8 & 9.9 & 39.4 & 41.5 & 40.8 & 33.5\end{array}$

Notes: Based on estimated exit hazard rates (for retirement and all other reasons). Faculty affected by mandatory retirement include person-year observations for individuals who were employed at an institution that was enforcing mandatory retirement in that year. 
Appendix Table 1: Faculty Retirement Survey Design

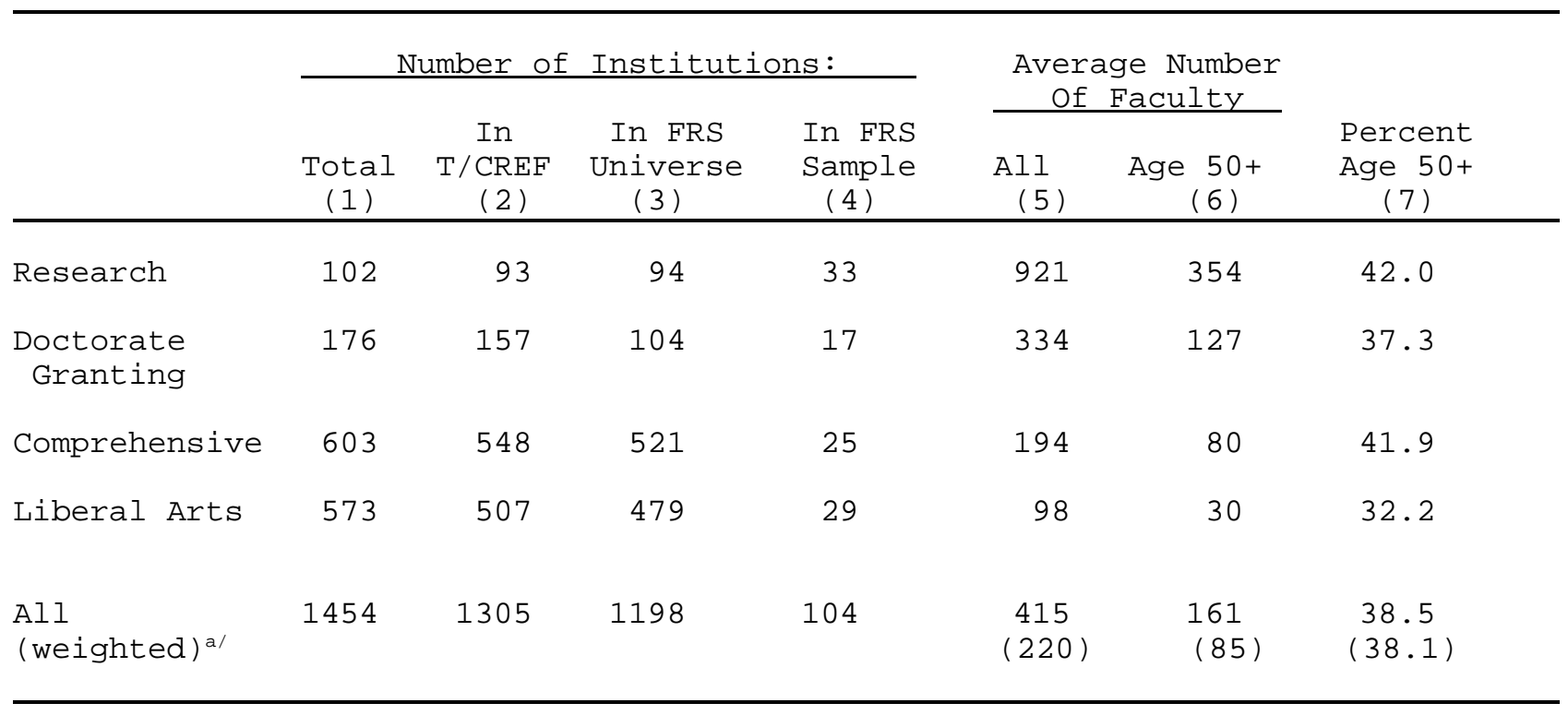

Notes: Column 1 is the number of accredited 4-year colleges and universities 7 in the sample frame of the 1992 National Survey of Postsecondary Faculty (NSPF) - see Table 5.1 of US Department of Education(1997). Column 2 is the estimated fraction of institutions that have at least some participation in TIAA-CREF, based on the results of the NSPF Institutional Survey (US Department of Education(1997, Table 5.1)). Column 3 is the number of institutions in the Faculty Retirement Survey (FRS) sample universe. This was obtained from a list of institutions with substantial TIAA-CREF participation in 1995, excluding specialized medical and law schools. Column 4 is the number of institutions that participated in the FRS survey, including 2 research universities and 2 comprehensive institutions from the pilot study. Columns 5-7 report the characteristics of the faculty in the FRS sample institutions, as of the survey baseline date (typically 1986). Total number of all faculty is missing for four schools.

a/The entry in parentheses is the weighted average, using FRS institutional sample weights. 
Appendix Table 2: Comparison of Faculty Characteristics in FRS and NSPF

\begin{tabular}{|c|c|c|c|c|c|c|c|c|}
\hline & \multicolumn{4}{|c|}{ Faculty Retirement Survey } & \multicolumn{4}{|c|}{ Nat. Survey of Postsecondary Faculty } \\
\hline & Research & Doctorate & Comp. & Lib. Arts & Research & Doctorate & Comp. & Lib. Arts \\
\hline Mean Age & 57.3 & 57.2 & 56.5 & 56.6 & 58.1 & 57.6 & 56.9 & 57.6 \\
\hline$\frac{\text { Age Distribution }(\%)}{50-54}$ & 35.1 & 36.0 & 40.8 & 41.4 & 34.0 & 37.5 & 41,1 & 36.1 \\
\hline $55-59$ & 31.9 & 31.4 & 32.0 & 29.8 & 30.0 & 27.9 & 29.2 & 29.7 \\
\hline $60-64$ & 22.9 & 23.2 & 21.2 & 21.6 & 20.8 & 20.4 & 19.6 & 21.6 \\
\hline $65+$ & 10.2 & 9.3 & 6.1 & 7.2 & 15.2 & 14.2 & 10.1 & 12.6 \\
\hline Percent Female & 12.3 & 14.2 & 20.4 & 20.2 & 12.2 & 18.3 & 26.1 & 28.6 \\
\hline Percent Nonwhite & 7.2 & 7.5 & 10.4 & 17.1 & 7.6 & 8.0 & 10.5 & 6.0 \\
\hline Percent With Ph.D. & 84.3 & 81.0 & 68.7 & 78.4 & 75.7 & 69.7 & 72.4 & 67.4 \\
\hline Percent Full Professor & 74.7 & 67.0 & 54.6 & 75.1 & 75.6 & 62.6 & 55.9 & 61.3 \\
\hline $\begin{array}{l}\text { Percent Arts and } \\
\text { Sciences }\end{array}$ & 52.8 & 51.9 & 53.7 & 77.3 & 44.4 & 41.6 & 47.5 & 62.1 \\
\hline Mean Salary (1996\$) & 73,200 & 65,200 & 52,000 & 56,800 & 79,500 & 67,600 & 54,700 & 48,200 \\
\hline Percent in TIAA-CREF & 78.0 & 83.5 & 71.2 & 91.4 & -- & -- & -- & -- \\
\hline Mean Pension (1996\$) & 255,200 & 220,000 & 119,000 & 195,900 & -- & -- & -- & -- \\
\hline No. Observations & 11,692 & 2,158 & 2,009 & 865 & -- & -- & -- & -- \\
\hline
\end{tabular}

Notes: Tabulations refer to faculty age 50 and older. Mean salary for FRS refers to salary in sample baseline year (typically 1986). Mean salary for NSPF refers to annual salary in 1992. Mean pension wealth refers to average accumulation (for those in TIAACREF) as of sample baseline year. Tabulations from NSPF were performed using the DAS system, using observations for tenured and tenure-track faculty at 4 year institutions age 50 and older. 
Figure 1: College Enrollment Inflows, 1955-1996

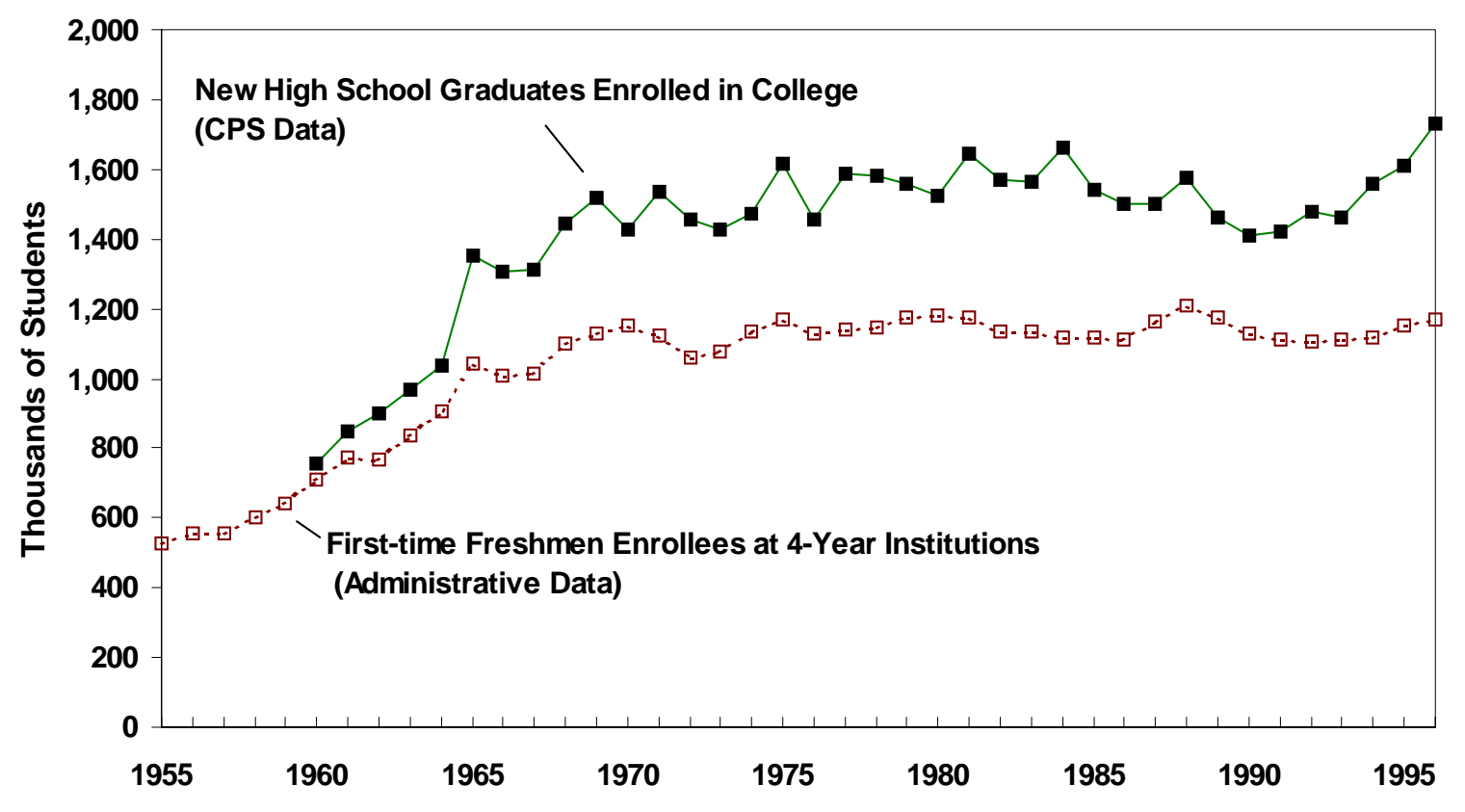


Figure 2: Age Distribution of Faculty and Four-Year Institutions, 1977, 1987, 1996

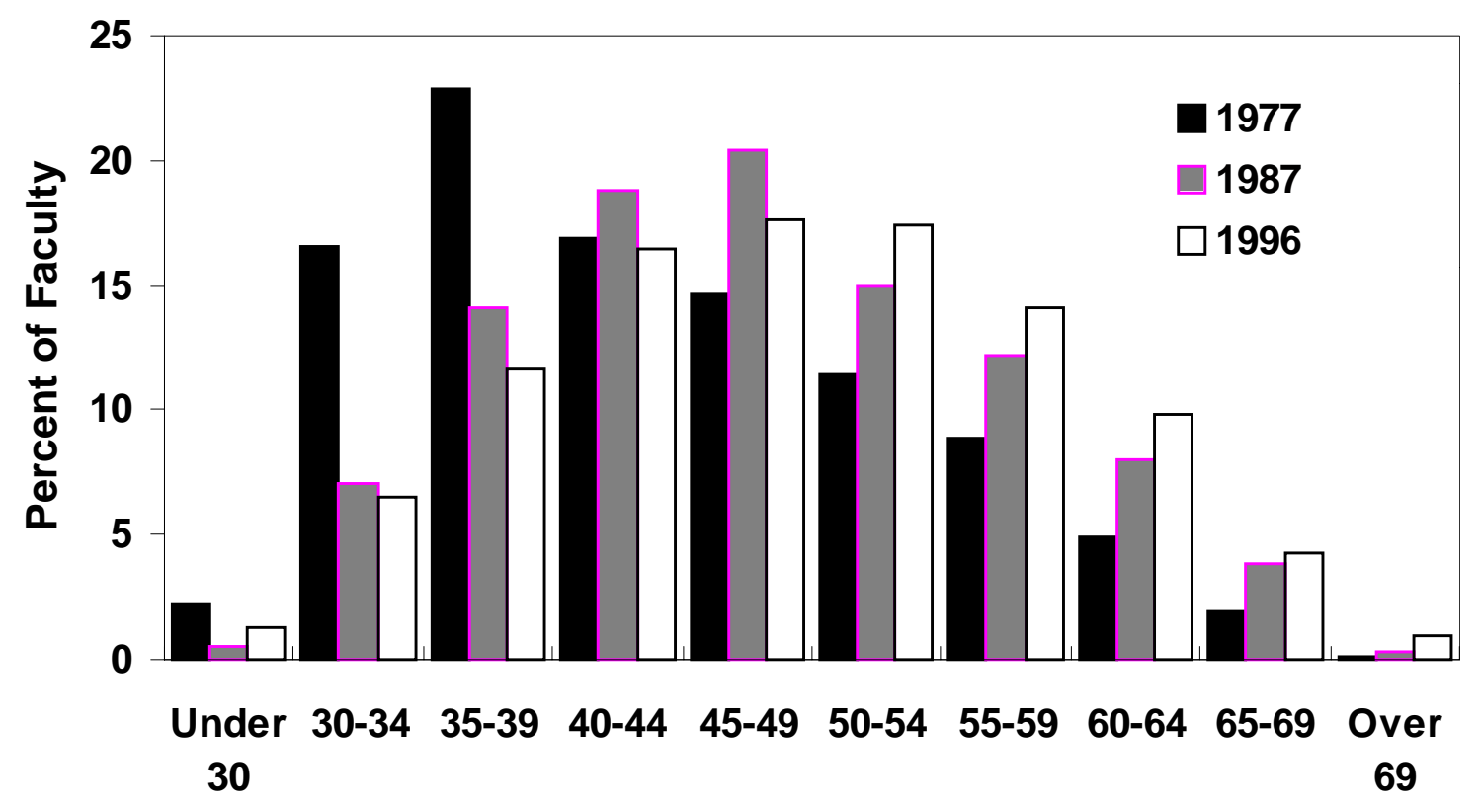


Figure 3: Age-Specific Exit Rates of Faculty at Capped Institutions, 1987-93

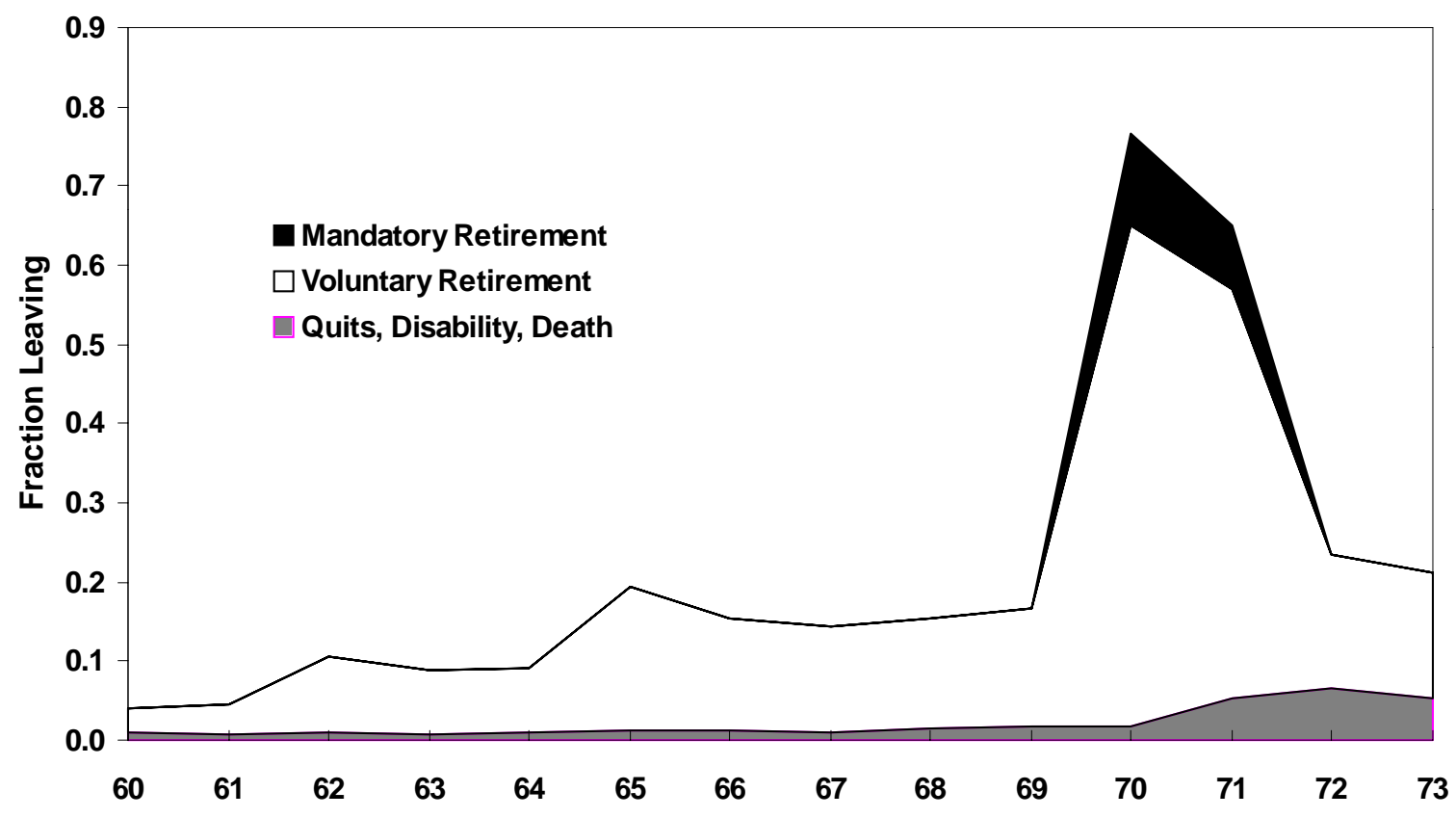


Figure 4: Age-Specific Exit Rates At Capped Institutions Before and After 1994

A. Retirement

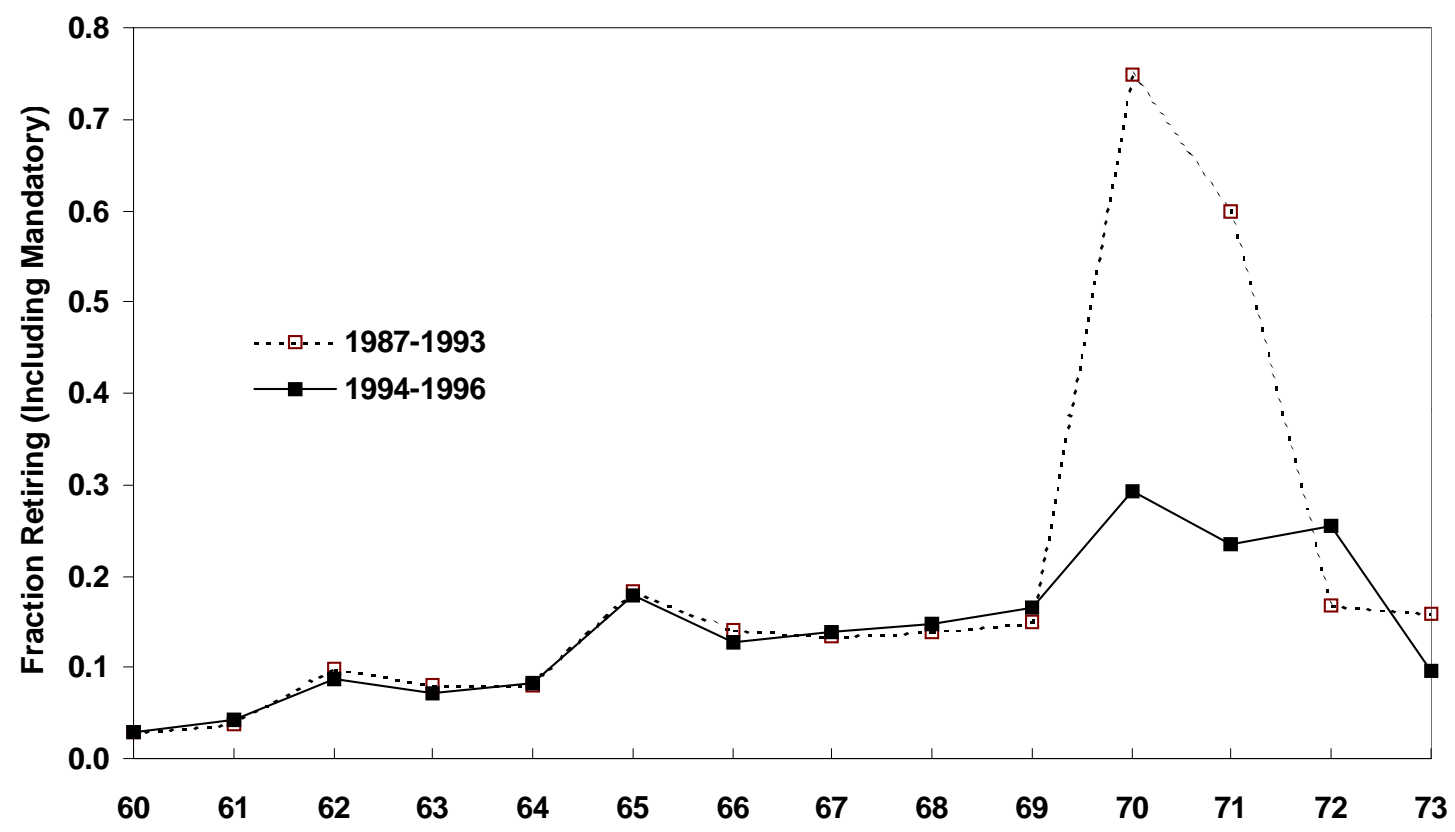

B. Other Exits

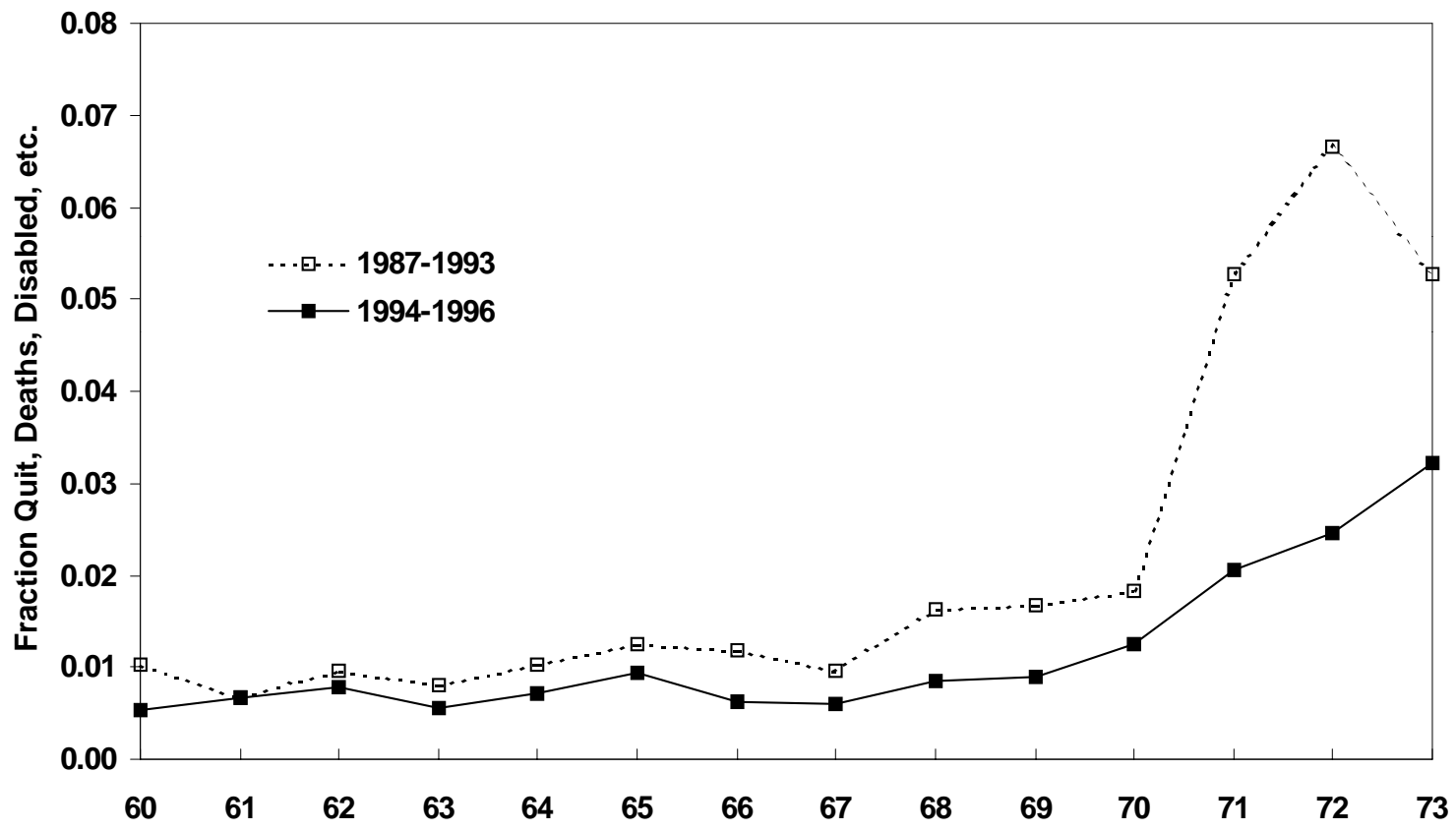


Figure 5: Age-Specific Retirement Rates at Capped Institutions, 1987-1996

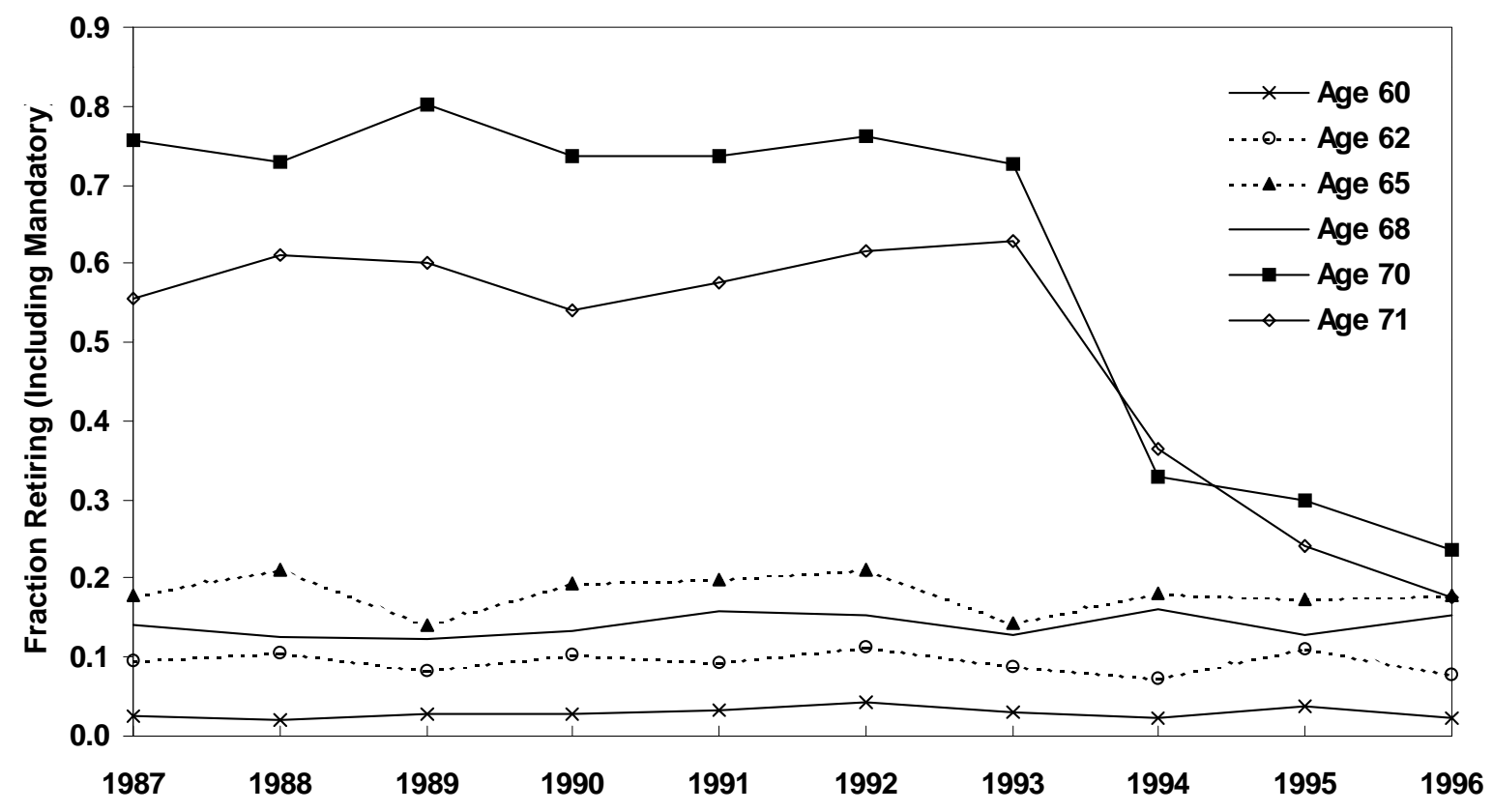


Figure 6: Retirement Rates at Age 70 at Three Groups of Institutions, 1987-1996

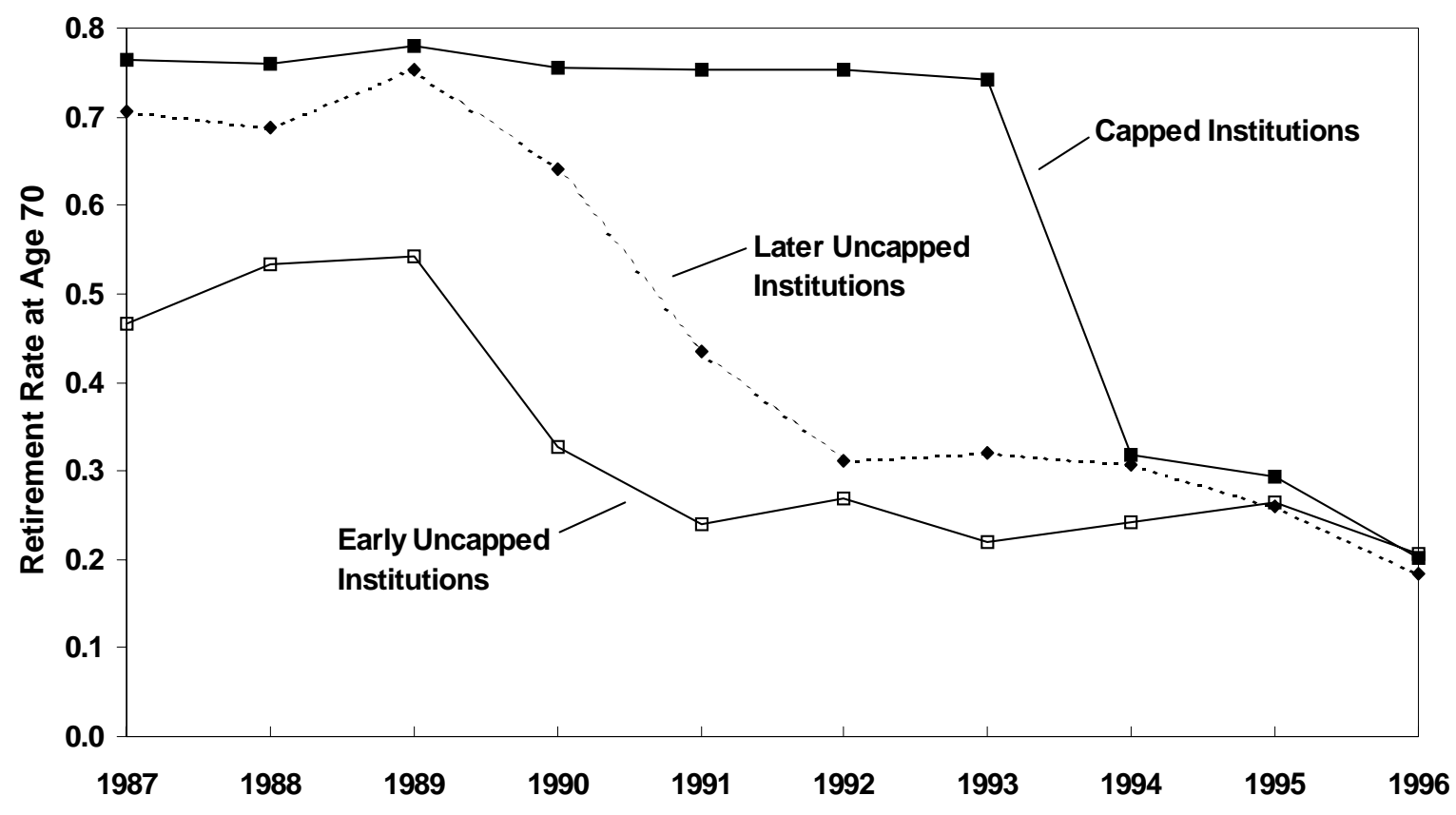


Figure 7: Distribution of Survival Rates from Age 60 to Age 70 Across Individual Institutions

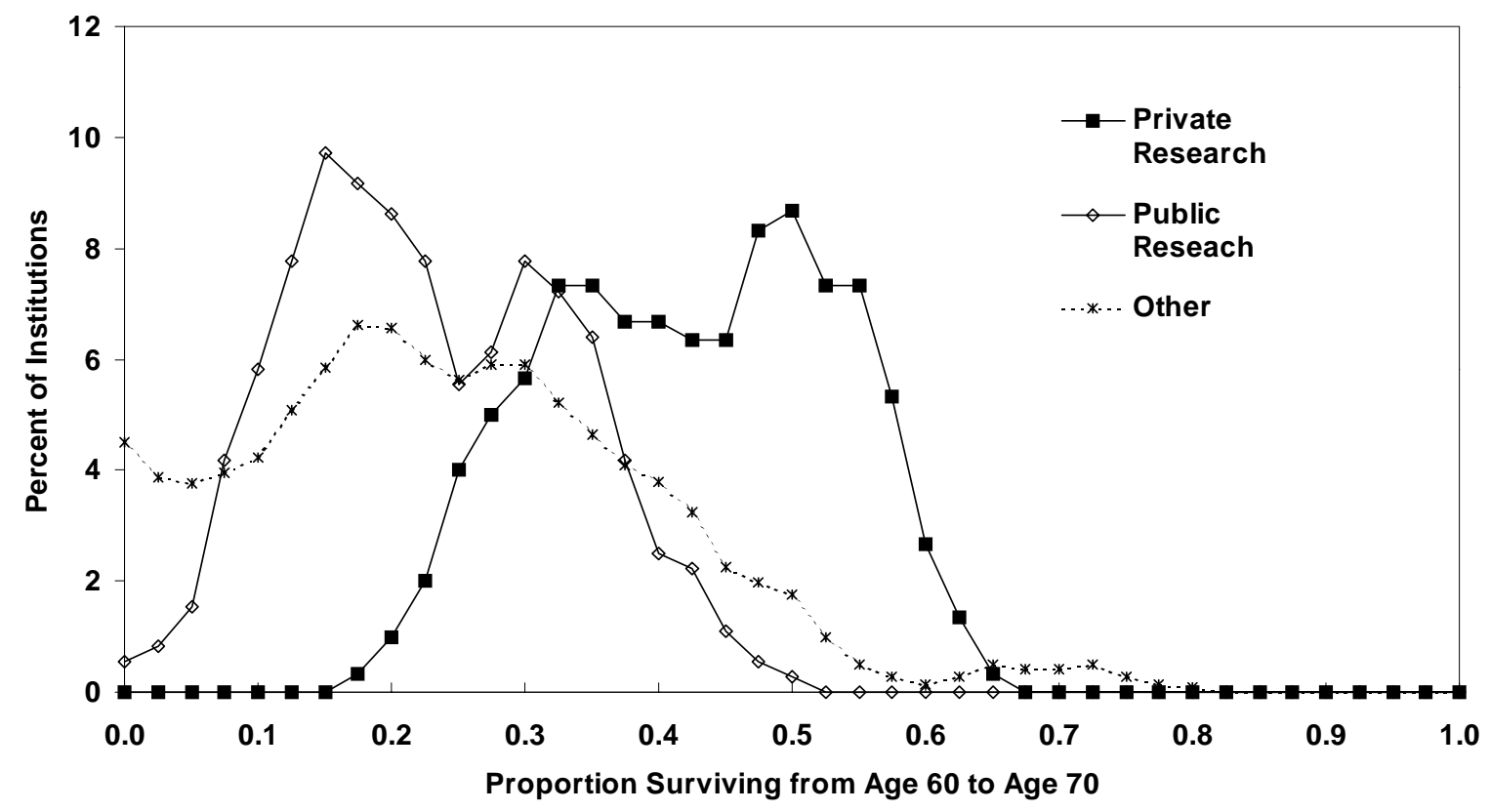


Figure 8: Age Profiles of Faculty Salaries in 1987 and 1996

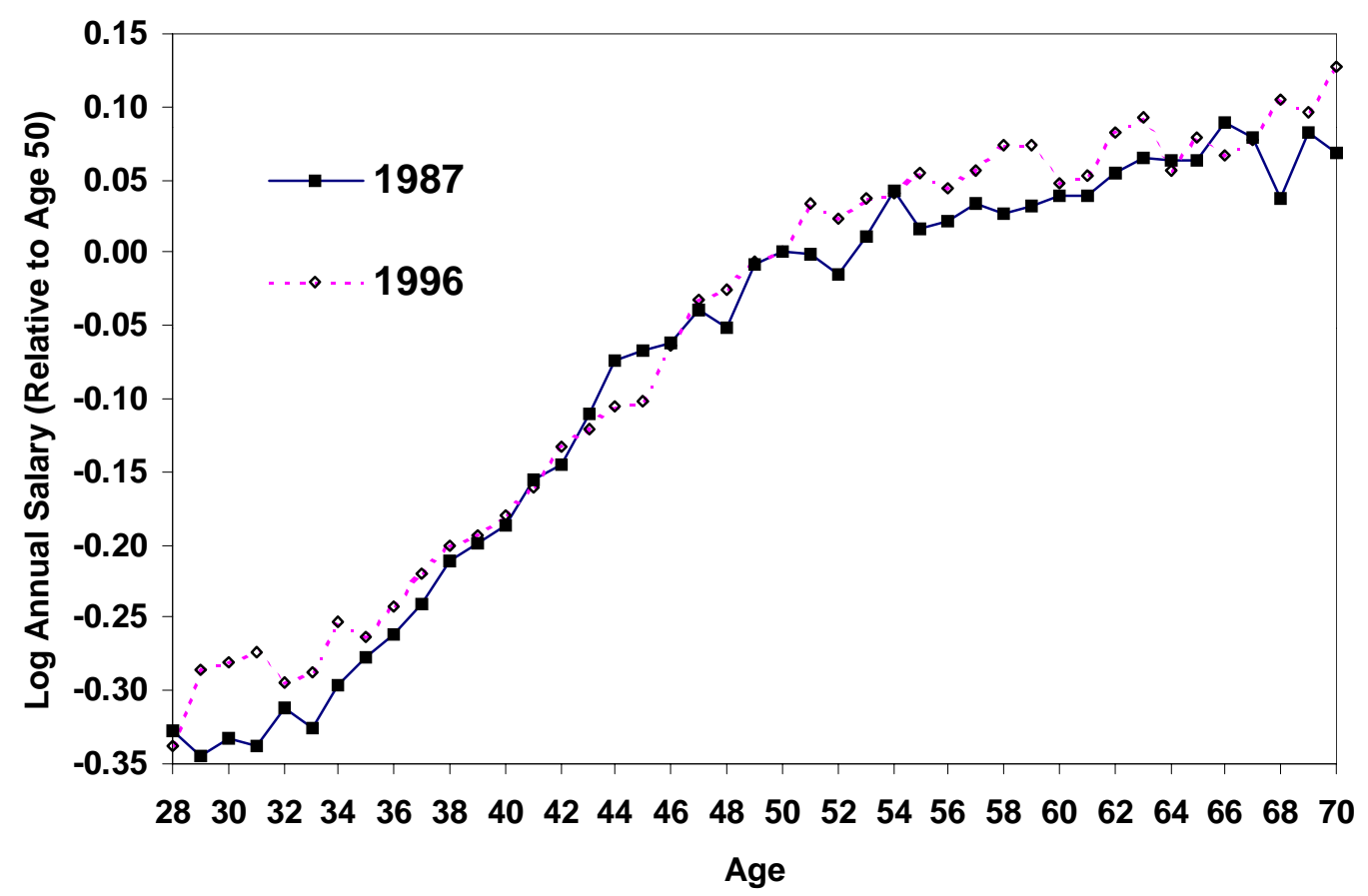

